WIDER Working Paper 2017/72

\title{
The missing middle
}

Growing and strengthening Viet Nam's micro, small, and medium-sized enterprises

Catherine Y. Co, ${ }^{1}$ Thu Kim Nguyen, ${ }^{2}$ Tung Nhu Nguyen, ${ }^{2}$ and Que Nguyet Tran ${ }^{3}$

March 2017 
Abstract: We study the exporting and subcontracting decisions, mark-ups, market concentration, and growth of a panel of Vietnamese private micro, small, and medium-sized enterprises. Our main findings are as follows. First, we find that among subcontractors, subcontracting is a supplementary rather than primary activity. Second, there is strong evidence that the propensity to export increases with managers' or owners' knowledge of customs law. Third, all else equal, markups are lower for larger micro, small, and medium-sized enterprises. Fourth, there is significant home province bias in the sales of Viet Nam's micro, small, and medium-sized enterprises. Membership of business associations and having internationally recognized quality certifications attenuate the size of the home market bias. Fifth, a significant number of enterprises did not grow or even contracted in size between 2010 and 2014. Finally, we find no evidence that inspections deter enterprises from expanding beyond their core competencies.

Keywords: Viet Nam, exporting, subcontracting, SME, enterprise growth, home market bias, mark-ups

JEL classification: F14, F61, L24, L25, O12

Acknowledgements: We thank Christine Ngo and participants at the 'Micro, Small, and Medium Enterprises in Viet Nam Workshop' (Hanoi, Viet Nam, 8 November 2016) for their helpful comments, and S.M. Shihab Siddiqui for valuable research assistance. Any remaining errors are our responsibility.

${ }^{1}$ Department of Economics, College of Business Administration, University of Nebraska at Omaha, Omaha, USA, corresponding author: cco@unomaha.edu. 2School of Business, Vietnam National University-International University, Ho Chi Minh City, Viet Nam; ${ }^{3}$ Humphrey Fellow 2016-17, State College, PA, USA.

This study has been prepared within the UNU-WIDER project on 'Structural transformation and inclusive growth in Viet Nam'.

Copyright (C) UNU-WIDER 2017

Information and requests: publications@wider.unu.edu

ISSN 1798-7237 ISBN 978-92-9256-296-0

Typescript prepared by Lesley Ellen.

The United Nations University World Institute for Development Economics Research provides economic analysis and policy advice with the aim of promoting sustainable and equitable development. The Institute began operations in 1985 in Helsinki, Finland, as the first research and training centre of the United Nations University. Today it is a unique blend of think tank, research institute, and UN agency — providing a range of services from policy advice to governments as well as freely available original research.

The Institute is funded through income from an endowment fund with additional contributions to its work programme from Denmark, Finland, Sweden, and the United Kingdom.

Katajanokanlaituri 6 B, 00160 Helsinki, Finland

The views expressed in this paper are those of the author(s), and do not necessarily reflect the views of the Institute or the United Nations University, nor the programme/project donors. 
Viet Nam's economic achievements since the start of đổi mớ $i$ in 1986 are remarkable. Real income per capita (purchasing power parity basis) in 1990 was only 5.2 per cent of the income levels of high-income Organisation for Economic Co-operation and Development (OECD) countries. By 2014, this had reached 13.1 per cent (World Bank 2015). More importantly, the percentage of the population living in poverty dropped from 77.1 per cent in 1992 to 13.9 per cent in 2012. ${ }^{1}$ Total factor productivity (TFP) growth accounts for most of Viet Nam's output growth in the 1990s as market-oriented policies led to the economy's restructuring. Since 1998, TFP growth has contributed minimally, if at all, to output growth (World Bank 2013). Viet Nam's economic achievements are partly due to export success predicated on low skill-intensive assembly work with minimal local content. Recent (2011) data show foreign-invested enterprises account for 56.9 per cent of Viet Nam's exports, 23.0 per cent of employment, and 20 per cent of gross domestic product (GDP) (WTO 2013). We argue that for TFP growth to be the primary driver of growth again, policies that strengthen the competitiveness of export-driven private micro, small, and medium-sized enterprises (MSMEs) while necessary, are not sufficient. ${ }^{2}$ Complementary policies that grow domestic market-oriented private MSMEs are equally important given Viet Nam's growing population and increasing income level. Because most private enterprises in Viet Nam are 'small' in size, ${ }^{3}$ their growth and increased competitiveness have the potential to make TFP growth the main driver of Viet Nam's growth once again.

Given the much reported policy bias in favour of state-owned enterprises and foreign-invested enterprises, we are most interested in understanding what makes Viet Nam's private MSMEs competitive internationally and domestically, and in how to strengthen and grow these enterprises. Viet Nam has streamlined procedures for starting a business. ${ }^{4}$ Thus, starting a business is not as difficult as in the past. The challenge now is how to grow a business from small, to medium, to large. As domestic private enterprises are relatively small (with 21 employees, on average, in 2011), they are unable to achieve the economies of scale necessary to be competitive. This is the so-called 'missing middle' (Dinh 2014). At the macro level, factors crucial to firm growth include protection accorded to minority investors, tax and trade rules, contract enforcement, and insolvency resolution. With the exception of trading across borders (at 67.2), Viet Nam's latest scores in the Doing Business indicators are low at 60 or less, with 100 being at the frontier (World Bank 2016a). Protection accorded to minority investors 'matters for the ability of companies to raise the capital they need to grow, innovate, diversify and compete' (World Bank 2016a: 65). An overly burdensome and complicated tax system incentivizes firms to remain unregistered and a small, well-functioning court system stimulates new business relationships, while a well-functioning insolvency resolution system safeguards creditor rights (World Bank 2016a).

Our paper has two main goals: to investigate how Viet Nam's MSMEs' access to credit (both formal and informal channels), prior knowledge of relevant laws, and technical capacity affect their exporting and subcontracting decisions, and how micro-equivalent measures of the macro factors described above correlate with their competitiveness (mark-ups, market concentration, and

\footnotetext{
${ }^{1}$ Based on a poverty line of $\$ 3.10 /$ day in 2011 PPP terms (World Bank 2015).

2 The limitation of China's export-driven growth is now apparent (Barone and Bendini, 2015; Akyuz, 2011).

${ }^{3}$ Based on employment size, micro, small, and medium-sized entities had a 98.5 per cent share of the total number of non-state enterprises in 2012 (Ministry of Planning and Investment 2014).

4 This includes dealing with construction permits, getting electricity, registering property, and access to credit. The country's scores on the Doing Business indices range from 63.3 to 82.2 (World Bank 2016a).
} 
growth). In the survey data we use, respondents say authorities can best 'help the enterprise expand and increase its profits' by providing access to credit (18.4 per cent indicate this as most important in the 2015 survey), by further removing bureaucratic requirements/restrictions (16.3 per cent), and through better private sector policies (12.9 per cent). Although only 6.1 per cent identify help 'through assistance with technical know-how' as most important, with Viet Nam's aim to boost the contribution of high-tech industries to 45 per cent of GDP by $2020,{ }^{5}$ we expect more MSMEs will require more help in this dimension in the future.

As early as 2001, policies to help Scale Manufacturing Enterprises (SMEs) had been adopted, but Decree No. 56/2009/NĐ-CP dated 30 June 2009 laid the foundation for a comprehensive approach to aid the development of SMEs in Viet Nam. Decree 56 includes provisions on credit access (e.g. establishment of a credit guarantee fund and technical help to meet creditor requirements). A development fund assists SMEs to develop more competitive and environmentfriendly products and invest in high-tech equipment and facilities. Provincial and city governments have developed areas for SMEs to cluster and thrive and have provided funds to help SMEs register and protect their intellectual property rights. Funds for productivity improvement, training, and market expansion are available. Decision No. 1231/QĐ-TTg dated 7 September 2012 approved the 2011-15 SME Development Plan which sought to increase the shares of SMEs to 40 per cent of GDP, ${ }^{6} 35$ per cent of investment, and 25 per cent of exports. Our study deals with three crucial aspects of SME development: credit access, information access, and innovation capability. $^{7}$

Participation in export markets remains low at 6-7 per cent of surveyed MSMEs. Briefly, we find that producing as subcontractor is a way to participate in export markets, and among the 10 per cent who produce as subcontractors, subcontracting is supplementary rather than primary activity. We find strong evidence that the propensity to export increases with managers' or owners' knowledge of customs law. Exporting likelihood is associated with new product and new process introductions while the likelihood of subcontracting is associated with product improvements. However, these results are sensitive to the sample used, and thus, conclusions related to technical capacity must remain tentative. Larger MSMEs earn lower mark-ups, all else equal. We also observe significant home province bias in Viet Nam's MSMEs' sales. Membership of business associations and international certifications attenuate the size of the home market bias. A significant number of enterprises did not grow, or even contracted in size, between 2010 and 2014, and there is no evidence that firm growth co-varies with access to finance or with the number of government inspections. Enterprises that are financially constrained are more likely to plan to start new projects or new product lines. We find no evidence that policy and technical compliance inspections deter enterprises from expanding beyond their existing core competencies.

In the next section, we provide an overview of relevant literature, data, and empirical methodology for the paper's first main contribution on the exporting and subcontracting decisions of enterprises. Baseline estimates and robustness checks are also included in this section. In section 3 , we investigate the determinants of the competitiveness of Vietnamese MSMEs using various

\footnotetext{
${ }^{5}$ Decision No. 418/QĐ-TTg dated 11 April 2012 contains Viet Nam's science and technology (S\&T) development strategy for 2011-20. For its economy to be among the most advanced in the Association of Southeast Asian Nations (ASEAN) region, public investment in S\&T is targeted to reach 2 per cent of GDP by 2020.

${ }^{6}$ According to the Ministry of Planning and Investment, the GDP share of SMEs reached 45 per cent at the end of 2015 (Bich 2016).

7 These fall under solution groups 2, 3, and 6 of the 2011-15 SME Development Plan.
} 
measures. Section 4 contains a discussion of the implications of our findings and concluding remarks.

\section{Exporting and subcontracting decisions}

\subsection{Related literature}

The presence of asymmetric information and unequal bargaining power among parties to a transaction are germane to our empirical work. Subcontracting arrangements fall between competitive spot bidding and organizing all firm activities in-house. Industrial organization-based models show that if production can be split into several stages, all activities will be organized inhouse if transaction and monitoring costs are 'high' (Kimura 2002). Competitive spot bidding is preferred when transaction and monitoring costs are 'low'. Commissioning firms (international or domestic producers, wholesalers, or retailers) choose subcontracting arrangements when transaction and monitoring costs are 'moderate'. No subcontracting offers are accepted if commissioning firms monopolize producer surpluses by exercising their dominant bargaining power over subcontractors (Razzolini and Vannoni 2011). Subcontracting arrangements entail a loss of control over some activities for subcontractors (e.g. input use must conform to commissioning firms' requirements) which are balanced against potential benefits (e.g. minimal up-front investments in building a network of buyers). For our purposes, MSMEs make a twopart decision: to export or not, and whether to produce as subcontractor or not. The first is a market entry decision while the second is an operation mode decision.

Subcontracting arrangements require an institutional environment where contracts are enforceable. When contract enforcement is weak, enterprises are less likely to enter into subcontracting arrangements due to the additional costs associated with finding alternative buyers if commissioning firms fail to honour contracts. Likewise, subcontracting arrangement exclusivity is dependent on the contract sensitivity of the products involved in the transactions. ${ }^{8}$ Exclusive subcontracting offers increase as products are required to conform to commissioning firms' specifications. An enforceable exclusive contract involves higher margins for subcontractors as products tend to be more specialized rather than homogeneous. Empirically, these suggest that subcontracting (compared to competitive spot bidding) is more likely in industries involving products that are more contract-intensive or differentiated.

Past studies on foreign market entry mode choice have traditionally looked at firms' choice among exporting, foreign direct investment, and licensing primarily because historically only developedcountry firms 'go global'. While there is growing literature on the internationalization strategies of emerging economy firms, the focus is mostly on 'large' firms. Thus, studies focus on greenfield versus acquisition strategies of emerging economy multinationals in developed markets (e.g. see Anderson and Sutherland 2015; Sun et al. 2012), or whether investments are made to access advanced technology such as Lenovo's acquisition of IBM's PC business. For MSMEs from developing countries, a more suitable choice set is whether to enter foreign markets (export directly or indirectly) or not, and whether to produce as subcontractor to commissioning firms or not. ${ }^{9}$ Subcontracting arrangements take various forms in developing countries. Most common is

\footnotetext{
${ }^{8}$ Bandyopadhyay et al. (2015) argue that the strength of contract enforcement affects the type of items traded. For example, inputs that are specialized or contract-intensive require a strong enforcement environment.

9 Subcontracting is the 'flip-side' of outsourcing, so the literature on outsourcing is useful here. Sharpston (1975) describes the development of international subcontracting and its essential features.
} 
subcontracting for foreign-invested enterprises in the garment industry in a number of countries such as Viet Nam and Laos wherein commissioning firms take the dominant role (e.g. Kongmanila and Takahashi 2009). SMEs face capital, technology, and market access constraints, thus working as subcontractors or suppliers to large multinational enterprises (MNEs) is one approach to surmounting these constraints. Being part of an international network opens new possibilities and provides opportunities for SMEs to build their capacity and enhance their competitiveness. This is why building inter-firm linkages among SMEs and MNEs is a high priority area for regional cooperation and integration of the Asia-Pacific Economic Cooperation forum (Wattanapruttipaisan 2002).

Melitz's (2003) model with heterogeneous firms and exporting fixed costs is also pertinent to our empirical work. In essence, Melitz's model predicts that the most productive firms service domestic and foreign markets, firms with intermediate productivity levels only service the domestic market, and the least productive firms would exit. Micro-data from various countries confirm the model's predictions. However, prior studies focus only on whether firms export or not (e.g. Berman and Héricourt 2010; Bernard and Jensen 2004) and firms' export intensity. Among myriad factors found to be important in firms' foreign market entry decisions (to export or not), we focus on firms' access to finance (both formal and informal sources), prior knowledge of relevant laws, and technical capacity. We consider not only the decision to export, but also the mode of operation (to be a subcontractor or not). ${ }^{10}$ Our empirical approach accounts for the possible correlation between these two decisions. Although enterprises in Viet Nam have been successful exporters, there are concerns that most are mere subcontractors or affiliates of foreign-invested enterprises or final assemblers of products using mostly imported inputs. ${ }^{11}$ Latest data (2011) show that 48.8 per cent of Viet Nam's manufactured gross exports are foreign value added, and for some types of machinery and equipment (not elsewhere classified) the rate is 71.1 per cent while for textiles, textile products, leather, and footwear the rate is 37.5 per cent (OECD 2015). ${ }^{12}$

The empirical evidence on the relationship between the decision to export and firms' financial position is mixed; Wagner (2014) gives a recent review of this literature. Bellone et al. (2010) find no relationship between firms' exporting propensity and financial position using French firm-level data while Japanese firms' exports are sensitive to the health of their reference banks (Amiti and Weinstein 2011). One reason for the mixed evidence might be due to the use of accounting data (e.g. liquidity ratio) to determine firms' financial position. Accounting-based measures have limitations in that a firm with low liquidity is either financially constrained (has weak fundamentals) or low liquidity is merely indicative of a firm having taken advantage of investment opportunities

\footnotetext{
${ }^{10}$ Tas and van Oyen (2000) describe early SME policy and strategy formulation in Viet Nam. They describe efforts to raise awareness among SMEs of the benefits of subcontracting, and modest attempts by the Vietnam Chamber of Commerce and Industry at matching potential subcontractors with contractors. These early attempts were largely unsuccessful due primarily to a weak institutional environment and limited local firm capabilities. Since then, the legal and regulatory environments are much improved, and subcontracting has become one of the cornerstones of Viet Nam's development strategy. In fact, the 2014 amendment to the Law on Investment provides preferential treatment to subcontractors (referred to as supporting industries) in support of select industries such as electronics. But, participation by Vietnamese-owned enterprises is hampered by their limited capabilities. For example, only 4 of Samsung's 61 suppliers in Viet Nam are Vietnamese-owned companies (OECD and the World Bank 2015).

${ }^{11}$ In the 2015 survey we use, subcontractors have a 13.5 per cent share of total full-time employment, a 9.9 per cent share of total physical assets, a 12.5 per cent share of total value added, and an 8.4 per cent share of total sales. We are unable to find information on the relative size of the subcontracting sector in Viet Nam, but there is anecdotal evidence that the majority of the subcontractors in Viet Nam are foreign-owned receiving materials, designs, and operations management from their foreign parents. Our contribution is to shed light on private and locally owned subcontracting operations in Viet Nam.

12 Shares for 1995 are respectively, 31.3, 49.8, and 35.5 per cent.
} 
(has strong fundamentals). As described in detail below, multiple questions in the surveys are direct indicators of firms' access to credit. These measures complement accounting-based measures. The role of access to finance on the decision to export among firms from developing countries is less understood and is, in fact, more relevant as financial constraints are more binding among firms from developing countries (Berman and Héricourt 2010). Using data from as many as 5,000 firms from nine developing and emerging countries, Berman and Héricourt (2010) find that the probability of exporting increases with the magnitude of firms' internal (cash flow-to-total asset ratio) and external (total debt-to-total asset ratio) funds.

Mixed evidence also characterizes the decision to subcontract and firms' financial position. Kimura (2002) finds no significant relationship between Japanese firms' financial position (proxied by the operating surplus to total sales ratio) and their decision to work as a subcontractor whereas Hayashi (2002) finds that metalworking and machinery firms with no problem accessing finance have higher subcontracting orders relative to total sales ratio in Indonesia. The author concludes that access to finance enables SMEs to fully exploit subcontracting opportunities with large-scale enterprises more easily.

It is widely believed that the availability of financing from informal creditors ${ }^{13}$ makes financial constraint less of a problem among MSMEs, and informal finance might be an important source of operational funds or expansion capital. One reason is because loans from banks can involve lengthy documentation while informal loans require little or no documentation (Khan 2015). Another reason for this is that, unlike banks, providers of informal credit are not required to meet capital, reserve, or liquidity requirements and other regulations (Waldron 1995). They can also collect information about borrowers at lower costs than banks due to having a prior relationship with borrowers (Lin and Sun 2006). Thus, informal lenders have more flexibility in structuring loan terms including the rate of interest, repayment schedule, and collateral requirement (Waldron 1995). The evidence on how access to informal finance impacts firms in developing countries is likewise mixed. One strand finds that firm performance (e.g. return on assets and net income reinvestment rate) improves with access to informal finance while bank loans have negligible effects (e.g. Su and Sun 2011). A second strand finds that funds from family and friends do not contribute to SME growth, and some forms of informal credit (e.g. borrowing from money lenders) are, in fact, detrimental to firm growth (e.g. Khan 2015).

The literature has emphasized the importance of the institutional context under which firms operate. For example, at the macro level, countries with better quality institutions do more trade (e.g. Méon and Sekkat 2008) and attract more foreign direct investment (e.g. Bénassy-Quéré et al. 2007). As discussed previously, subcontracting arrangements are more likely when contracts are enforceable, as both parties to the contract receive protection. At the micro level, we argue that while the institutional environment firms operate in is relevant, knowledge of existing laws by owners or managers is equally relevant. As far as we can tell, no one has formally explored the possibility that current knowledge of relevant laws by owners or managers might affect their foreign market entry and mode of operation decisions. When studying MSMEs, knowledge of existing laws is crucial. Limited or lack of knowledge of customs procedures or regulations might prevent even the most successful small, domestic market-oriented enterprises from expanding into foreign markets. Limited or lack of knowledge of regulations governing investments hinders enterprises from taking full advantage of preferences available for those operating in support (e.g.

\footnotetext{
13 This includes financing provided by non-bank financial institutions, trade credit (Su and Sun 2011), and financing from friends and family (Khan 2015). McMillan and Woodruff (1999) find network effects in the extent of use and provision of trade credit in the late 1990s in Vietnam. In their sample, 22 per cent of the surveyed firms receive bank credit while 57 per cent (53 per cent) provide trade credit to their customers (receive trade credit from their suppliers).
} 
subcontractor) of select activities such as garment production. Viet Nam's 2011-15 SME Development Plan recognizes the importance of access to information. It specifically provides for the establishment of an information network where the public can easily access legal documents and portals to disseminate policies and government programmes available to SMEs.

There is some evidence that the propensity to export increases with new product introductions. Bernard and Jensen (2004) find export probability increases by about 3 per cent whenever US plants experience a change in their industry classification (interpreted as new product introductions by the authors) for plants operating from 1984 to 1992. It is important to note that there is a strand of literature studying the interdependence between the decision to export and the decision to innovate. For example, for a panel of German firms, Becker and Egger (2013) find that both product and process innovation increase the likelihood that firms export, and the estimated effect is larger for product innovation. For MSMEs from developing countries, the adoption of new processes (which increase efficiency) or merely coming out with better versions of existing products might be a sufficient threshold to compete internationally. Our paper is closest in sprit to Nguyen at al. (2008) who use the 2005 version of the survey. They find that product innovation, process innovation, and product modification all contribute to the likelihood of exporting, with process innovation having the smallest coefficient estimate in the probit regressions. ${ }^{14} \mathrm{We}$ build on their work by considering a wider set of issues after Viet Nam's entry to the World Trade Organization (WTO) and after the global financial crisis of 2008.

\subsection{Data}

We use data from the 2011, 2013, and 2015 versions of the 'Survey of Small and Medium Scale Manufacturing Enterprises (SMEs) in Viet Nam' made available by the United Nations University World Institute for Development Research (UNU-WIDER). To administer the biennial surveys, UNU-WIDER collaborates with Viet Nam's Central Institute for Economic Management (CIEM) of the Ministry of Planning and Investment (MPI) and the Institute of Labour Science and Social Affairs (ILSSA) of the Ministry of Labour, Invalids, and Social Affairs (MoLISA). Viet Nam defines industrial micro enterprises as those with employment not exceeding ten people. Smallsized enterprises have over ten but under 200 employees and capital not exceeding VND 20 billion, while medium-sized enterprises have over 200 but under 300 employees with capital of over VND 20 billion but under VND 100 billion $^{15}$ (Ministry of Planning and Investment 2014). The surveys were administered in Hanoi, Ho Chi Minh City, Hai Phong, Long An, Phu Tho, Quang Nam, Nghe An, Khanh Hoa, and Lam Dong. These cover northern, central, and southern regions of the country. Stratified sampling ensures representation by ownership type across the nine areas. The surveys include non-state manufacturing enterprises only.

The survey asks whether an enterprise is an exporter, direct exporter, and whether it produces as a subcontractor. Exporter is set to 1 if an enterprise exports directly or indirectly (through intermediaries) while direct exporter equals 1 for direct exporters, 0 otherwise. Note that direct exporters is a subset of exporters. Subcontractor is set equal to 1 for subcontractors, 0 otherwise.

\footnotetext{
${ }^{14}$ Nguyen et al. (2008) report a much higher proportion of enterprises conducting these three types of activities: 41 per cent introduced new products, 30 per cent introduced new processes, and 60 per cent modified existing products. We find much lower proportions in our sample. It is possible that the high rates in the 2005 survey are in preparation for Viet Nam's entry to the WTO in 2007 or a consequence of the signing of the US-Vietnam Bilateral Trade Agreement in 2001.

15 These are about US\$900,000 and US\$4.5 million, respectively at an exchange rate of VND 22,000/USD.
} 
Summary statistics for these three variables for the full sample appear in Table $1 .{ }^{16}$ In the three survey years, 6-7 per cent are exporters, ${ }^{17} 3-4$ per cent are direct exporters, ${ }^{18}$ and 10 per cent are subcontractors. Among exporters, 15-19 per cent are subcontractors while 9-12 per cent of the subcontractors are exporters. Among direct exporters, 12-18 per cent produce as subcontractors, and 4-8 per cent of the subcontractors are direct exporters. Very few are both exporters and subcontractors in all survey years. The Pearson $\chi^{2}$ statistics lead to the rejection of the null hypothesis that the decision to export and produce as subcontractor is independent at the 1 per cent level of significance. For direct exports, the null hypothesis is rejected at the 5 per cent level only in 2015. These suggest some evidence that the two decisions are inter-related; thus, our estimation approach below accounts for this possibility.

Among exporters (direct exporters), the mean value of the exports to total revenue share is 26-31 per cent (44-63 per cent) while the mean subcontracting to revenue share is 11-14 per cent. For the most part, among exporters, subcontractors have higher (mean) exporting rates. However, based on the Wilcoxon rank-sum tests, we fail to reject the hypothesis that the distributions of exporting rates between subcontractors and non-subcontractors are equal. Likewise, among subcontractors, non-exporters have higher (mean) subcontracting rates. However, there is weak evidence that the distributions of the subcontracting rates are different among exporters and nonexporters. Since the survey excludes joint ventures with foreign capital, the data suggest that among Viet Nam's MSMEs, subcontracting work is a way to participate in foreign markets (since among exporters, exporting rates are higher for subcontractors compared to non-subcontractors), but subcontracting work is a supplementary rather than primary activity (since subcontracting rates are low overall).

\footnotetext{
16 The entire dataset has 7,702 observations. The summary statistics in Table 1 exclude observations with more than 300 full-time employees and those classified as service providers, or data for these three variables are missing.

17 Nguyen et al. (2008) report that 6 per cent of the enterprises in the 2005 SME survey export. Using 2005-11 Enterprise Surveys (covering all registered manufacturing enterprises with 30 employees or more and a representative sample of small enterprises), Newman et al. (2014) document an export rate of 15 per cent (2005) to 32 per cent (2011).

${ }^{18}$ This rate is comparable to that in 2002 wherein Kokko and Sjöholm (2005) document that 3 per cent of the surveyed MSMEs are direct exporters.
} 
Table 1: Exporting and subcontracting rates, full sample

\begin{tabular}{|c|c|c|c|}
\hline \multirow[t]{2}{*}{ Item } & \multicolumn{3}{|c|}{ Survey Year } \\
\hline & 2015 & 2013 & 2011 \\
\hline Exporters (per cent) & 6.9 & 6.2 & 6.0 \\
\hline Direct exporters (per cent) & 4.3 & 3.0 & 2.7 \\
\hline Subcontractors (per cent) & 9.9 & 10.4 & 10.3 \\
\hline No. of enterprises & 2,595 & 2,498 & 2,456 \\
\hline A. Exporter and Subcontractor (per cent) & 1.2 & 1.2 & 0.9 \\
\hline Pearson, chi-sq., $p$-value & 0.000 & 0.001 & 0.060 \\
\hline \multicolumn{4}{|l|}{ Among exporters: } \\
\hline Subcontractors (per cent) & 17.9 & 18.6 & 14.9 \\
\hline \multicolumn{4}{|l|}{ Exports/Revenue (mean, per cent): } \\
\hline Combined & 27.5 & 25.9 & 31.0 \\
\hline Subcontractors & 30.9 & 22.8 & 35.0 \\
\hline Non-subcontractors & 26.7 & 26.6 & 30.4 \\
\hline Wilcoxon rank-sum test, $p$-value & 0.461 & 0.529 & 0.684 \\
\hline \multicolumn{4}{|l|}{ Among, subcontractors: } \\
\hline Exporters (per cent) & 12.4 & 11.2 & 8.7 \\
\hline \multicolumn{4}{|l|}{ Subcontracts/revenue (mean, per cent): } \\
\hline Combined & 14.2 & 10.7 & 12.6 \\
\hline Exporters & 9.1 & 8.0 & 11.3 \\
\hline Non-exporters & 14.9 & 11.1 & 12.7 \\
\hline Wilcoxon rank-sum test, $p$-value & 0.113 & 0.155 & 0.040 \\
\hline B. Direct Exporter and Subcontractor (per cent) & 0.8 & 0.4 & 0.4 \\
\hline Pearson, chi-sq., $p$-value & 0.000 & 0.638 & 0.189 \\
\hline \multicolumn{4}{|l|}{ Among direct exporters: } \\
\hline Subcontractors (per cent) & 18.0 & 12.0 & 15.2 \\
\hline \multicolumn{4}{|l|}{ Exports/revenue (mean, per cent): } \\
\hline Combined & 44.3 & 51.3 & 63.1 \\
\hline Subcontractors & 49.4 & 59.6 & 72.5 \\
\hline Non-subcontractors & 43.2 & 50.2 & 61.5 \\
\hline Wilcoxon rank-sum test, $p$-value & 0.446 & 0.575 & 0.387 \\
\hline \multicolumn{4}{|l|}{ Among, subcontractors: } \\
\hline Direct exporters (per cent) & 7.8 & 3.5 & 4.0 \\
\hline \multicolumn{4}{|l|}{ Subcontracts/revenue (mean, per cent): } \\
\hline Combined & 14.2 & 10.7 & 12.6 \\
\hline Direct exporters & 9.2 & 3.9 & 10.6 \\
\hline Non-direct exporters & 14.6 & 11.0 & 12.7 \\
\hline Wilcoxon rank-sum test, $p$-value & 0.380 & 0.012 & 0.497 \\
\hline
\end{tabular}

Source: Authors' calculations using data from the 2011, 2013, and 2015 Survey of Small and Medium Scale Manufacturing Enterprises (SMEs) in Viet Nam (UNU-WIDER et al. various years). 


\subsection{Empirical methodology}

We distinguish four types of enterprises: non-subcontractors who do not export (base or control group), subcontractors who do not export, non-subcontractors who export, and subcontractors who export. ${ }^{19}$ As noted previously, subcontract work is ancillary activity for Viet Nam's MSMEs, and the evidence is compatible with the view that subcontract work allows enterprises to enter foreign markets. Thus, the decisions of whether to export or not $\left(y_{1}\right)$ and whether to be a subcontractor or not $\left(y_{2}\right)$ might be correlated decisions. The bivariate random effects (panel) probit model is appropriate for studying this. The two decisions (outcomes) are determined by two unobserved latent variables $\left(y_{1}^{*}\right.$ and $\left.y_{2}^{*}\right)$ :

$$
\begin{aligned}
y_{1 i t}^{*}=x_{i t}^{\prime} \beta_{1}+z_{1 i t}^{\prime} \gamma_{1}+ & u_{1 i}+\varepsilon_{1 i t} \\
& y_{2 i t}^{*}=x_{i t}^{\prime} \beta_{2}+z_{2 i t}^{\prime} \gamma_{2}+u_{2 i}+\varepsilon_{2 i t},
\end{aligned}
$$

where $\boldsymbol{x}$ includes regressors common to both decisions while $\boldsymbol{z}_{\mathbf{1}}$ and $\mathbf{z}_{\mathbf{2}}$ include regressors relevant to each decision. The $u_{i}^{\prime}$ s are enterprise-specific $(\imath)$ errors which are time invariant. Each $u_{j}$ is normally distributed with mean 0 and variance $\sigma_{u_{j}}^{2}$, where $j=1,2$. The $\varepsilon_{i t}$ 's are random errors and $\varepsilon_{1}$ and $\varepsilon_{2}$ are jointly normally distributed with means of 0 and variances equal to 1 , and a correlation equal to $\varrho .{ }^{20}$ The two observed outcomes are defined as follows:

$$
\begin{aligned}
& y_{1}=\left\{\begin{array}{l}
1 \text { if } y_{1}^{*}>0 \\
0 \text { if } y_{1}^{*} \leq 0
\end{array}\right. \\
& y_{2}= \begin{cases}1 & \text { if } y_{2}^{*}>0 \\
0 & \text { if } y_{2}^{*} \leq 0\end{cases}
\end{aligned}
$$

Note that $y_{1}=0$ and $y_{2}=0$ is the base or control group, and if $\varrho$ is equal to zero, the bivariate probit regression model is equivalent to two separate probit regression models. With the exception of three factors, the same specification is used for both decision equations as factors that are associated with market entry decisions are more likely also associated with mode of operation choices.

\section{Baseline specification}

We start with Berman and Héricourt's (2010) baseline specification in defining matrix $\boldsymbol{x}$. Matrix $\boldsymbol{x}$ includes period, location, sector, and ownership type qualitative indicators, firm size, productivity, and access to credit. Two period indicators (SY15 and SY13 is set to 1 for 2015 and 2013, respectively, 0 otherwise) control for time-specific shocks that affect all enterprises in the same way. Survey year 2011 is the base period. The location indicators account for city or province-level differences in characteristics or policies towards MSMEs while the sector indicators account for sector-level differences in fixed costs that might affect MSMEs' exporting and subcontracting

\footnotetext{
${ }^{19}$ We should note that, although our dataset contains information on revenue from subcontracts, we do not know how much of the subcontracting revenue was exported (directly or indirectly through trading companies) and how much is from domestic sales.

${ }^{20}$ A non-zero correlation means that unobserved characteristics that make enterprises more (less) likely to be exporters overlap with unobserved characteristics that make them more (less) likely to be subcontractors. Ignoring the potential correlation between the error terms of the two decision equations might lead to incorrect inferences. See Greene (2000) for details. We use Plum's (2016) bireprob routine (for Stata) which allows $\varepsilon_{1}$ and $\varepsilon_{2}$ to be correlated, and for the random effects error terms $\left(u_{1}\right.$ and $\left.u_{2}\right)$ to be correlated as well.
} 
decisions. We define three location indicators: Hanoi, Ho Chi Minh City, and Hai Phong. These are large metropolitan areas in Viet Nam. All other areas comprise the base location. We hypothesize that enterprises in these three metropolitan areas are more likely to be exporters and independent operators. We also define eight qualitative indicators for the main sector that enterprises operate in with basic and fabricated metal products as the reference sector. Two qualitative indicators define an enterprise's ownership type. Ownership1 is set equal to 1 for sole proprietorships, partnerships, and collectives/cooperatives; 0 otherwise. Ownership2 is set equal to 1 for limited liability companies and joint stock companies without state capital; 0 otherwise. Household establishments form the base category for ownership type. Among the three ownership types, household establishments (base category) are expected to have the lowest propensity to export or to produce as subcontractors, followed by sole proprietorships, partnerships, and collectives/cooperatives; then lastly, by limited liability companies and joint stock companies.

Firm size is proxied by total assets and labour productivity is the ratio of value added over the number of full-time workers. We use the natural $\log$ of these variables. Size is a cost shifter; larger enterprises may face lower costs, thus are more likely to export (also see Bernard and Jensen 2004) or to operate as subcontractors. The likelihood of exporting is expected to be positively associated with productivity (Bernard and Jensen 2004) and so is the likelihood of being a subcontractor. We would ideally prefer to estimate productivity using Levinsohn and Petrin's (2003) methodology, but data limitation prevents us from doing so. ${ }^{21}$

To provide an in-depth understanding of how finance correlates with exporting and subcontracting decisions, four measures are used. The ratio of cash flow-to-total assets measures the availability of internal funds. Cash flow funds day-to-day operations. The ratio of total debtto-total assets is used as indicator of the availability of external funds. It is widely believed that firms' inability to access formal credit markets force them to tap informal credit markets; thus, besides an enterprise's access to formal credit, we also consider informal credit accessibility. The survey asks several credit-related questions: whether the enterprise has applied for bank loans or other formal credit or informal credit since the last survey, whether the enterprise encountered problems in getting credit, and whether the enterprise needs more credit. We define two variables using responses to these questions. Following Rand (2007), constrained1 is set equal to 1 if an enterprise has applied for formal credit and indicates 'in need of a loan', regardless of whether it encountered problems in getting credit or not, equal to 0 otherwise. Notice that an enterprise that did not apply for formal credit is considered financially unconstrained using this definition. ${ }^{22}$ This creates a self-selection problem in that enterprises expecting not to qualify for formal credit (say from prior experience) will not apply altogether, and will use informal credit channels instead. To account for this, we set constrained 2 to 1 when conditions for the first definition are satisfied and when an enterprise did not apply for formal credit but did apply for informal credit because it 'couldn't get formal credit'. This partly mitigates the self-selection problem described above.

All else equal, we hypothesize that enterprises with access to internal or external finance are more likely to export and not to produce as subcontractors. Exporting requires large up-front investments, and access to finance provides enterprises with the necessary liquidity or investment capital to enter foreign markets (e.g. Berman and Héricourt 2010). Enterprises prefer to earn as

\footnotetext{
${ }^{21}$ Raw material usage is not available in the 2015 survey, so this leaves us with two years of data. We are unable to use Levinsohn and Petrin's (2003) methodology to estimate productivity because it requires lagged values of the exogenous variables as instruments, and this requirement leaves us with one year of data. The methodology requires a minimum of three years of data.

22 Another problem source is that in the 2011 and 2013 surveys, the question 'are you in need of a loan' is asked only when an enterprise applied for a formal loan since the last survey.
} 
much of the producers' surplus as possible. Intuitively, subcontractors earn a smaller portion of the surplus compared to non-subcontractors. One reason for choosing the subcontracting option is limited access to finance to purchase raw material inputs. Commissioning firms might supply the needed inputs in a subcontracting arrangement whereas a loan might be required when the enterprise is not a subcontractor. ${ }^{23}$ Thus, access to finance increases the likelihood of not producing as a subcontractor.

\section{Additional regressors}

We expand Berman and Héricourt's (2010) specification. Average monthly wages paid to production workers (wages) is indicative of the quality of an enterprise's production workers (Bernard and Jensen 2004), and there is evidence in the literature that the probability of exporting increases with labour quality (e.g. Schank et al. 2010). Viet Nam's comparative advantage is in the production of unskilled labour-intensive goods, so we expect the probability of exporting and subcontracting to be positively correlated with the proportion of production workers to total employment (production worker share).

There is reason to believe that knowledge of relevant laws is a crucial determinant of business decisions. This stems from the results of a recent survey that find that very few Vietnamese businesses have taken advantage of the benefits emanating from Viet Nam's existing free trade agreements (The Economist Intelligence Unit 2014); either their knowledge of the benefits is minimal or they find the rules too troublesome to learn. The Law on Customs and the Law on Investment are relevant for our purposes. Responses to 'How would you characterize knowledge about the following laws and government regulations' range from 1 (good) to 4 (no knowledge/no interest). The Law on Customs governs exporting and importing activities in Viet Nam, we hypothesize that the likelihood of exporting increases with knowledge of the Law on Customs. The Law on Investments regulates investment activities of domestic and foreign investors in Viet Nam, so we expect knowledge of this particular law to affect subcontracting decisions, but exactly how is ambiguous. While knowledge of the law increases the likelihood of operating independently because the manager/owner is aware of the 'rules of the game', knowledge of the law might also increase the likelihood of producing as a subcontractor because the law covers business cooperation contracts, wherein parties cooperate in production (Article 232005 Law on Investment). ${ }^{24}$

Bernard and Jensen (2004) find that US plants introducing new products (new product is set equal to 1) have a higher likelihood of exporting. New product introductions expand enterprises' markets via the product space. In the context of developing-country MSMEs, the ability of MSMEs to compete internationally might not require new product group introductions; mere adoption of

\footnotetext{
23 This is consistent with Manova and Yu's (2015: 8) argument that 'most financially constrained exporters will conduct pure assembly and earn low profits.... Least financially constrained exporters will conduct ordinary trade and earn the highest profits'.

24 Prior to 2010, neither law contained specific provisions for MSMEs or preferential treatment for subcontractors. In 2010, goods exported or imported for processing under a subcontracting agreement were exempt from export and import taxes (Article 12, Decree No. 87/2010/NĐ-CP). Certain provisions of the Law on Investment (as amended in 2014) and Circular 96/2015/TT-BTC are relevant to subcontracting decisions. Article 16 of the Law on Investment provides preferential treatment to enterprises operating in support of these industries: garment, textile, leather products, electronics, prioritized mechanical products, agricultural machinery, automobiles, automobile parts, shipbuilding, and high-tech industries. Preferential treatment as specified in Article 15 includes lower corporate income tax rate for a definite period or for the duration of the investment project, or exemption from corporate income tax; exemption from import duty for capital goods, raw materials, and supplies and components; and, exemption from or reduction of land rent, land use fees, and land use tax.
} 
new processes or technology (new process is set to 1) or coming out with better versions of existing products (product improvement is set to 1) might be sufficient thresholds for exporting. According to Esteve-Pérez and Rodríguez (2013), process innovations 'associated with cost-savings and improvements in technical conditions, enhance firm efficiency, which could prompt export market participation' (Esteve-Pérez and Rodríguez 2013: 234). Product improvements broaden or lengthen enterprises' market reach. We expect these to increase the likelihood of exporting and being independent operators, and prior research (e.g. Nguyen et al. 2008) suggests that the estimated effects on the likelihood to export is larger for new product introductions than for new process adoption.

Lastly, we include one more control in the subcontracting equation. Sharpston (1975) emphasizes that 'subcontracting avoids the problems of marketing: outlets, brand names, publicity, market research, design' (Sharpston 1975: 118). Using this logic, a priori, we expect enterprises that advertise (advertise set equal to 1) are less likely to be subcontractors.

Because we are unable to distinguish between exit and exit from the survey, we only use enterprises surveyed in all three years in our panel regressions $(1,189$ enterprises, excluding observations with incomplete information). Table 2 contains (overall) summary statistics for our sample. ${ }^{25}$ On average, our sample has 15 full-time employees, each of whom generates VND 46 million of value added. The mean cash flow-to-total assets and total debt-to-total assets ratios are about 0.10. Data show about 21-23 per cent are financially constrained. On average, the monthly wage of a production worker is about VND 1.5 million and production workers comprised 66 per cent of the workforce. Knowledge of the Law on Customs and Law on Investment is 'poor'. About 10 per cent of the enterprises introduced new products and adopted new processes; about a quarter made improvements to existing products. About 16 per cent of the enterprises advertise. The pairwise correlations among all continuous variables appear in Table 3 for reference. They range from -0.33 (total assets and knowledge of customs law) and 0.58 (knowledge of customs and investment laws).

\footnotetext{
${ }^{25}$ The entire dataset has 7,702 observations with 1,721 enterprises surveyed in three years, 757 in two years, and 1,025 in one year. We use the consumer price index to convert nominal to real $(2005=100)$ values.
} 
Table 2: Summary statistics, estimation sample.

\begin{tabular}{lllll}
\hline & Mean & Std. Dev. & Min. & Max. \\
\hline Exporter & 0.08 & 0.28 & 0 & 1 \\
Direct exporter & 0.04 & 0.19 & 0 & 1 \\
Subcontractor & 0.11 & 0.31 & 0 & 1 \\
Assets (million VND) & $6,341.97$ & $23,414.23$ & 15.50 & $921,004.80$ \\
Labour productivity (million VND) & 46.10 & 76.80 & 0.10 & $2,950.00$ \\
Cash flow-to-asset ratio & 0.10 & 0.12 & 0 & 0.96 \\
Debt-to-asset ratio & 0.09 & 0.22 & 0 & 4.38 \\
Constrained1 & 0.21 & 0.41 & 0 & 1 \\
Constrained2 & 0.23 & 0.42 & 0 & 1 \\
Wages (thousand VND) & $1,470.52$ & 706.55 & 1.62 & $22,000.00$ \\
Production worker share & 0.66 & 0.18 & 0 & 0.98 \\
Customs law & 3.60 & 0.73 & 1 & 4 \\
Investment law & 3.40 & 0.83 & 1 & 4 \\
Advertise & 0.16 & 0.37 & 0 & 1 \\
New product & 0.11 & 0.31 & 0 & 1 \\
Product improvement & 0.27 & 0.44 & 0 & 1 \\
New process & 0.10 & 0.29 & 0 & 1 \\
\hline
\end{tabular}

Note: Sample: balanced panel. Number of enterprises =1,189; number of observations $=3,567$.

Source: Authors' calculations using data from the 2011, 2013, and 2015 Survey of Small and Medium Scale Manufacturing Enterprises (SMEs) in Viet Nam (UNU-WIDER et al. various years). 
Table 3: Correlation coefficients

\begin{tabular}{lllllllll}
\hline & & $(1)$ & $(2)$ & $(3)$ & $(4)$ & $(5)$ & $(6)$ & $(7)$ \\
\hline Assets (log) & $(1)$ & 1.000 & & & & & & \\
Labour productivity (log) & $(2)$ & 0.389 & 1.000 & & & & & \\
Cash flow-to-asset ratio & $(3)$ & -0.246 & 0.008 & 1.000 & & & & \\
Debt-to-asset ratio & $(4)$ & 0.020 & 0.063 & 0.064 & 1.000 & & & \\
Wages (log) & $(5)$ & 0.271 & 0.287 & 0.016 & 0.034 & 1.000 & & \\
Production worker share & $(6)$ & 0.213 & 0.007 & -0.050 & 0.032 & 0.287 & 1.000 & \\
Customs law & $(7)$ & -0.333 & -0.189 & -0.014 & -0.066 & -0.115 & -0.040 & 1.000 \\
Investment law & $(8)$ & -0.322 & -0.151 & -0.026 & -0.080 & -0.137 & -0.023 & 0.578 \\
\hline
\end{tabular}

Note: Sample: balanced panel. Number of enterprises $=1,189$; number of observations $=3,567$.

Source: Authors' calculations using data from the 2011, 2013, and 2015 Survey of Small and Medium Scale Manufacturing

Enterprises (SMEs) in Viet Nam (UNU-WIDER et al. various years). 


\subsection{Analysis of results}

As described previously, we use four proxies for access to finance and three proxies for technical capacity. We estimate equation (1) using 12 specifications each for exporter and direct exporter as one of the regressands. As we detail below, there is weak evidence that access to finance affects MSMEs' exporting/subcontracting decisions. Thus, to conserve space, we only provide estimates for three specifications (one finance variable with the three proxies for technical capacity). ${ }^{26}$ Table 4 contains bivariate random effects probit estimates for select variables using the broad exporter definition. The correlation of the residuals between the two decision equations range from 0.14 to 0.16 , and are not significantly different from zero in all specifications. The estimates using direct exporter as regressand are in Table 5. The cross-equation correlations are also not significantly different from zero, and range from -0.13 to -0.17 . Patterns described below are based on coefficient estimates that are statistically significant at the 10 per cent level.

There is some evidence that the propensity to export and produce as subcontractor have increased over time (SY15 has larger positive coefficient estimates than SY13 when statistically significant). Regardless of which exporter definition is used, compared to MSMEs in less urbanized regions of the country, we consistently find that MSMEs in Hanoi and Ho Chi Minh City have higher (lower) likelihood of exporting (producing as subcontractors). Compared to those in basic and fabricated metal manufacturing, MSMEs in other sectors have higher propensity to export (with MSMEs in leather and wood production having the highest propensity to export). MSMEs in food manufacturing have the lowest probability of producing as subcontractors. Compared with basic and fabricated metal products, a smaller proportion of food products is identified by Rauch (1999) as differentiated, so this result is consistent with our expectations that subcontracting is more likely in industries involving products that are differentiated. Not surprisingly, household enterprises have the lowest likelihood of exporting while there is no evidence that subcontracting decisions are a function of ownership type.

The propensity to export and to produce as subcontractor are positively associated with firm size (log of assets) as expected. Given Viet Nam's comparative advantage in labour-intensive products, enterprises with higher production worker shares have higher propensity to export. Exporting and subcontracting decisions do not appear to be associated with labour productivity or workforce quality.

${ }^{26}$ All regression estimates are available upon request. 
Table 4: Bivariate random effects probit regressions. Dependent variables: exporter (yes, no); subcontractor (yes, no)

\begin{tabular}{|c|c|c|c|c|c|c|}
\hline & \multicolumn{2}{|l|}{ (1) } & \multicolumn{2}{|l|}{ (2) } & \multicolumn{2}{|l|}{ (3) } \\
\hline & $\exp$ & subc & $\exp$ & subc & $\exp$ & subc \\
\hline \multirow[t]{2}{*}{ Assets $(\log )$} & $0.374^{\star * *}$ & $0.102^{* * *}$ & $0.363^{* * *}$ & $0.102^{* * *}$ & $0.353^{* * *}$ & $0.099^{* * *}$ \\
\hline & $(0.09)$ & $(0.03)$ & $(0.09)$ & $(0.03)$ & $(0.29)$ & $(0.03)$ \\
\hline \multirow[t]{2}{*}{ Labour productivity (log) } & 0.127 & -0.041 & 0.129 & -0.043 & 0.117 & -0.043 \\
\hline & $(0.11)$ & $(0.05)$ & $(0.11)$ & $(0.05)$ & $(0.11)$ & $(0.05)$ \\
\hline \multirow[t]{2}{*}{ Cash flow-to-asset ratio } & $1.279^{*}$ & 0.335 & $1.217^{*}$ & 0.346 & $1.310^{\star *}$ & 0.335 \\
\hline & $(0.65)$ & $(0.29)$ & $(0.64)$ & $(0.29)$ & $(0.65)$ & $(0.29)$ \\
\hline \multirow[t]{2}{*}{ Wages (log) } & 0.060 & 0.073 & 0.061 & 0.068 & 0.064 & 0.072 \\
\hline & $(0.14)$ & $(0.05)$ & $(0.14)$ & $(0.05)$ & $(0.14)$ & $(0.05)$ \\
\hline \multirow[t]{2}{*}{ Production worker share } & $2.778^{\star \star \star}$ & -0.040 & $2.838^{\star * \star}$ & -0.048 & $2.831^{* \star *}$ & -0.026 \\
\hline & $(0.59)$ & $(0.21)$ & $(0.58)$ & $(0.21)$ & $(0.59)$ & $(0.21)$ \\
\hline \multirow[t]{2}{*}{ Customs law } & $-0.429^{\star \star \star}$ & - & $-0.422^{\star * *}$ & - & $-0.411^{\star \star \star}$ & - \\
\hline & $(0.09)$ & & $(0.09)$ & & $(0.09)$ & \\
\hline \multirow[t]{2}{*}{ Investment law } & - & $0.083^{*}$ & - & $0.088^{* *}$ & - & $0.087^{\star *}$ \\
\hline & & $(0.04)$ & & $(0.04)$ & & $(0.04)$ \\
\hline \multirow[t]{2}{*}{ Advertise } & - & $0.159^{*}$ & - & 0.140 & - & 0.156 \\
\hline & & $(0.10)$ & & $(0.10)$ & & $(0.10)$ \\
\hline \multirow[t]{2}{*}{ New prod. introduction } & $0.721^{\star \star \star}$ & 0.150 & - & - & - & - \\
\hline & $(0.26)$ & $(0.11)$ & & & & \\
\hline \multirow[t]{2}{*}{ Old prod. improvement } & - & - & $0.299^{*}$ & $0.233^{* * *}$ & - & - \\
\hline & & & $(0.16)$ & $(0.07)$ & & \\
\hline \multirow[t]{2}{*}{ New process adoption } & - & - & - & - & $0.640^{\star * *}$ & $0.211^{*}$ \\
\hline & & & & & $(0.22)$ & $(0.11)$ \\
\hline \multirow[t]{2}{*}{$\rho$} & 0.137 & & 0.146 & & 0.158 & \\
\hline & $(0.17)$ & & $(0.16)$ & & $(0.17)$ & \\
\hline Log likelihood & $-1,674.63$ & & $-1,673.11$ & & $-1,673.44$ & \\
\hline Wald chi-sq & $140.96^{\star \star *}$ & & $146.67^{\star \star \star}$ & & $145.92^{* \star *}$ & \\
\hline No. of enterprises & 1,189 & & 1,189 & & 1,189 & \\
\hline No. of observations & 3,567 & & 3,567 & & 3,657 & \\
\hline
\end{tabular}

Notes: Sample: balanced panel. Numbers in parentheses are standard errors. Regressions include a constant term, complete sets of time, location, industry, and ownership type qualitative indicators as described in the text. ${ }^{* * *},{ }^{* *},{ }^{*}$ statistically significant at the $1,5,10$ per cent level.

Source of data: 2011, 2013, and 2015 Survey of Small and Medium Scale Manufacturing Enterprises (SMEs) in Viet Nam (UNU-WIDER et al. various years). 
Table 5: Bivariate random effects probit regressions. Dependent variables: direct exporter (yes, no); subcontractor (yes, no)

\begin{tabular}{|c|c|c|c|c|c|c|}
\hline & \multicolumn{2}{|l|}{ (1) } & \multicolumn{2}{|l|}{ (2) } & \multicolumn{2}{|l|}{ (3) } \\
\hline & $\exp$ & subc & $\exp$ & subc & $\exp$ & subc \\
\hline \multirow[t]{2}{*}{ Assets (log) } & $0.557^{\star \star *}$ & $0.115^{\star * \star}$ & $0.539^{* * *}$ & $0.113^{\star * *}$ & $0.536^{\star * \star}$ & $0.110^{\star \star *}$ \\
\hline & $(0.13)$ & $(0.03)$ & $(0.13)$ & $(0.03)$ & $(0.13)$ & $(0.03)$ \\
\hline \multirow[t]{2}{*}{ Labour productivity (log) } & 0.179 & -0.038 & 0.179 & -0.040 & 0.153 & -0.039 \\
\hline & $(0.15)$ & $(0.06)$ & $(0.15)$ & $(0.06)$ & $(0.16)$ & $(0.06)$ \\
\hline \multirow[t]{2}{*}{ Cash flow-to-asset ratio } & -0.093 & 0.298 & -0.036 & 0.306 & -0.098 & 0.297 \\
\hline & $(0.93)$ & $(0.30)$ & $(0.90)$ & $(0.30)$ & $(0.96)$ & $(0.30)$ \\
\hline \multirow[t]{2}{*}{ Wages (log) } & -0.007 & 0.075 & -0.007 & 0.071 & -0.010 & 0.075 \\
\hline & $(0.28)$ & $(0.05)$ & $(0.27)$ & $(0.05)$ & $(0.29)$ & $(0.05)$ \\
\hline \multirow[t]{2}{*}{ Production worker share } & $3.155^{\star \star \star}$ & -0.042 & $3.249^{* * *}$ & -0.050 & $3.320^{\star \star \star}$ & -0.024 \\
\hline & $(0.93)$ & $(0.22)$ & $(0.93)$ & $(0.22)$ & $(0.94)$ & $(0.22)$ \\
\hline \multirow[t]{2}{*}{ Customs law } & $-0.773^{\star \star *}$ & - & $-0.767^{\star \star \star}$ & - & $-0.762^{\star \star \star}$ & - \\
\hline & $(0.13)$ & & $(0.13)$ & & $(0.13)$ & \\
\hline \multirow[t]{2}{*}{ Investment law } & - & $0.092^{* *}$ & - & $0.097^{* *}$ & - & $0.096^{* *}$ \\
\hline & & $(0.04)$ & & $(0.04)$ & & $(0.04)$ \\
\hline \multirow[t]{2}{*}{ Advertise } & - & $0.173^{*}$ & - & 0.150 & - & $0.170^{\star}$ \\
\hline & & $(0.10)$ & & $(0.10)$ & & $(0.10)$ \\
\hline \multirow[t]{2}{*}{ New prod. introduction } & 0.100 & 0.167 & - & - & - & - \\
\hline & $(0.37)$ & $(0.11)$ & & & & \\
\hline \multirow[t]{2}{*}{ Old prod. improvement } & - & - & 0.270 & $0.245^{\star * *}$ & - & - \\
\hline & & & $(0.24)$ & $(0.08)$ & & \\
\hline \multirow[t]{2}{*}{ New process adoption } & - & - & - & - & $0.785^{\star *}$ & $0.220^{\star *}$ \\
\hline & & & & & $(0.31)$ & $(0.11)$ \\
\hline \multirow[t]{2}{*}{$\rho$} & -0.13 & & -0.16 & & -0.17 & \\
\hline & $(0.19)$ & & $(0.19)$ & & $(0.19)$ & \\
\hline Log likelihood & $-1,390.12$ & & $-1,385.58$ & & $-1,385.92$ & \\
\hline Wald chi-sq & $86.03^{\star \star \star}$ & & $86.81^{* * *}$ & & $84.44^{* \star *}$ & \\
\hline No. of enterprises & 1,189 & & 1,189 & & 1,189 & \\
\hline No. of observations & 3,567 & & 3,567 & & 3,657 & \\
\hline
\end{tabular}

Notes: Sample: balanced panel. Numbers in parentheses are standard errors. Regressions include a constant term, complete sets of time, location, industry, and ownership type qualitative indicators as described in the text. ${ }^{* \star *},{ }^{* *},{ }^{*}$ statistically significant at the $1,5,10$ per cent level.

Source: 2011, 2013, and 2015 Survey of Small and Medium Scale Manufacturing Enterprises (SMEs) in Viet Nam (UNU-WIDER et al. various years).

There is weak evidence that MSMEs' financial condition affects both decisions. In some specifications, when statistically significant, cash flow-to-total assets and total debt-to-total assets ratios have positive coefficients. The two financial constraint variables constructed from creditrelated survey questions are mostly statistically insignificant. The evidence (albeit weak) suggests that enterprises with high liquidity or leverage are more likely to be exporters. In this context, high liquidity is indicative of solid fundamentals allowing enterprises to expand their market reach overseas. Likewise, assuming more debt allows enterprises to expand their market base. Perhaps finding that MSMEs' financial positions do not correlate well with their foreign market strategies and modes of operation should not be surprising as shortage of capital is not as important a growth 
constraint as in the past. Shortage of capital was the most important growth constraint for 45 per cent of the survey respondents in 2011 (just after the global financial crisis), but in 2015, only 19.9 per cent identify shortage of capital as the most important growth constraint. Moreover, this is significantly lower compared to a decade ago.

There is strong evidence that the probability of exporting increases with a manager's or owner's self-reported knowledge of customs law (recall, low values indicate 'good' knowledge of the law) while the probability of producing as subcontractor is higher when knowledge of the investment law is 'poor'. Creation and expansion of information networks and portals for SME expansion is one of the objectives of the 2011-15 SME Development Plan. To the extent that these informational campaigns have reached the MSMEs in our sample, our results suggest that these campaigns have had the intended effects of affecting business decisions.

The likelihood that MSMEs export (broad definition) is associated with the introduction of new products or improvement of existing products. The propensity to export (both definitions) is associated with the introduction of new production processes or technology. Recall that exporting directly requires larger up-front investments (e.g. building a buyer network) compared to exporting indirectly through trading companies, so only the most competitive are direct exporters. Our results suggest that Vietnamese MSMEs' ability to compete directly in the international marketplace is primarily due to their process rather than product advantages. MSMEs with new or improved versions of existing products are internationally competitive only if they can achieve cost savings through the use of trading companies to access foreign markets. Both product improvements and adoption of new production processes or technology increase the likelihood that MSMEs produce as subcontractors. These results are intuitive as subcontractors respond to commissioning firm requirements. Supporting the use of new technology and strengthening the innovative capacity of SMEs are also part of the 2011-15 SME Development Plan. If the MSMEs in our sample benefited directly (through R\&D incentives) or indirectly (through better access to information about science, technology, and intellectual property) from the technology-related provisions of the 2011-15 SME Development Plan, then our findings imply some level of success for these policies in impacting business outcomes.

Before turning to the economic significance of our main results, we account for potential endogeneity described in the next sub-section. ${ }^{27}$

\footnotetext{
27 Equation (1) is also estimated excluding unregistered household enterprises. For the most part, our previous observations hold. Because of their informal status, unregistered enterprises have less degrees of freedom in terms of their market entry choices and modes of operation, this constraint potentially explains why the two decisions appear unrelated when informal firms are included in the sample. Interestingly, the cross-equation correlations are statistically significant at the 10 per cent level for the regressions using the broad exporter definition whereas they remain statistically insignificant using the stricter (direct exporter) definition. We should note that a comprehensive approach to SME development was adopted in 2009, and one objective is to help SMEs (household enterprises) register and move out of the informal sector. We observe a significant decrease in the number of unregistered household enterprises in our estimation sample (defined as either not having an Enterprise Code Number or a combined Tax Code Number and Business Registration Certificate) from 19 per cent (2011 survey) to 3 per cent (2015 survey). This could be partly due to Resolution No. 19/NQ-CP issued on 13 August 2014 wherein changes in procedures led to a reduction in time to prepare and settle tax obligations from 537 hours to 117 hours between 2014 and 2015. The distinction between registered and unregistered enterprises is not as important as before; this is why the conclusions are broadly similar with or without unregistered enterprises in the sample. We keep unregistered enterprises in our sample.
} 


\subsection{Robustness check}

To mitigate potential endogeneity (e.g. as enterprises engage in exporting or subcontracting, their owners/managers learn relevant laws), we estimate equation (1) using lagged values of all righthand-side variables. As before, the cross-equation correlations are not significantly different from zero at the 10 per cent level. Thus, we can reasonably be confident that estimating the two equations separately using the random effects probit model would provide similar conclusions. ${ }^{28}$ The marginal effects for these probit regressions appear in Table 6. We find that the negative coefficient for knowledge of customs law remains statistically significant at the 1 per cent level when lagged knowledge of the law is used as regressor. This suggests that our conclusion that the likelihood of exporting increases with knowledge of customs laws is appropriate. We find that a 1point drop in knowledge of customs law (e.g. improvement from 'poor' (3) to 'average' (2)) increases the exporting likelihood by 0.014 to 0.021 . These marginal effects appear small, but considering that only 8.4 per cent (0.084) of the MSMEs in the sample export, these marginal effects, in fact, are economically meaningful. Consider this counterfactual. If all MSMEs' knowledge of customs law is 'average' (index value of 2), the (average) predicted probability of exporting (broad definition) increases to 0.120 (with a standard error of 0.013 ) up from 0.074 (0.007) when knowledge of customs law is 'poor' (index value of 4). The probability increases to 0.150 (0.022) if knowledge of the law improves to 'good' (index value of 1).

The propensity to export and work as subcontractor is no longer associated with technical capacity in the lagged specification. Except for lagged firm size, lagged values of the regressors are not statistically significant in the subcontracting equation. Thus, our conclusion related to the determinants of subcontracting must remain tentative with regard to potential endogeneity of some of the regressors (e.g. potential feedback between knowledge of investment law and subcontracting decisions), although the lack of statistical significance is not as surprising as one might suppose as subcontractor status is not persistent from year to year: Only 28 per cent $(20$ per cent) of the subcontractors in the 2011 survey remain as subcontractors in the 2013 (2015) survey. So it might be contemporaneous enterprise characteristics that matter in whether to produce as subcontractor or not.

28 We use Stata's xtprobit routine which unlike Plum's (2016) bireprobit provides standard errors clustered at the enterprise level. 
Table 6: Average marginal effects using single-equation random effects probit model, lagged specification

\begin{tabular}{|c|c|c|c|c|c|c|c|c|c|}
\hline & \multicolumn{3}{|l|}{$(1)$} & \multicolumn{3}{|l|}{ (2) } & \multicolumn{3}{|l|}{ (3) } \\
\hline & $\exp$ & direct & subc & $\exp$ & direct & subc & $\exp$ & direct & subc \\
\hline Assets (log) & $\begin{array}{l}0.023^{\star \star *} \\
(0.01)\end{array}$ & $\begin{array}{l}0.011^{\star * *} \\
(0.003)\end{array}$ & $\begin{array}{l}0.012^{*} \\
(0.01)\end{array}$ & $\begin{array}{l}0.023^{\star \star \star} \\
(0.01)\end{array}$ & $\begin{array}{l}0.011^{* * *} \\
(0.003)\end{array}$ & $\begin{array}{l}0.012^{*} \\
(0.01)\end{array}$ & $\begin{array}{l}0.023^{\star * *} \\
(0.01)\end{array}$ & $\begin{array}{l}0.011^{* * *} \\
(0.003)\end{array}$ & $\begin{array}{l}0.012^{*} \\
(0.01)\end{array}$ \\
\hline $\begin{array}{l}\text { Labour } \\
\text { productivity (log) }\end{array}$ & $\begin{array}{l}0.007 \\
(0.01)\end{array}$ & $\begin{array}{l}0.003 \\
(0.005)\end{array}$ & $\begin{array}{l}0.001 \\
(0.01)\end{array}$ & $\begin{array}{l}0.008 \\
(0.01)\end{array}$ & $\begin{array}{l}0.004 \\
(0.005)\end{array}$ & $\begin{array}{l}0.001 \\
(0.01)\end{array}$ & $\begin{array}{l}0.007 \\
(0.01)\end{array}$ & $\begin{array}{l}0.004 \\
(0.005)\end{array}$ & $\begin{array}{l}0.001 \\
(0.01)\end{array}$ \\
\hline $\begin{array}{l}\text { Cash flow-to- } \\
\text { asset ratio }\end{array}$ & $\begin{array}{l}0.063^{*} \\
(0.03)\end{array}$ & $\begin{array}{l}0.033 \\
(0.02)\end{array}$ & $\begin{array}{l}0.080 \\
(0.06)\end{array}$ & $\begin{array}{l}0.065^{*} \\
(0.03)\end{array}$ & $\begin{array}{l}0.037^{*} \\
(0.02)\end{array}$ & $\begin{array}{l}0.081 \\
(0.06)\end{array}$ & $\begin{array}{l}0.064^{*} \\
(0.03)\end{array}$ & $\begin{array}{l}0.035 \\
(0.02)\end{array}$ & $\begin{array}{l}0.080 \\
(0.06)\end{array}$ \\
\hline Wages (log) & $\begin{array}{l}-0.014 \\
(0.01)\end{array}$ & $\begin{array}{l}0.007 \\
(0.01)\end{array}$ & $\begin{array}{l}0.005 \\
(0.01)\end{array}$ & $\begin{array}{l}-0.014 \\
(0.01)\end{array}$ & $\begin{array}{l}0.005 \\
(0.01)\end{array}$ & $\begin{array}{l}0.006 \\
(0.01)\end{array}$ & $\begin{array}{l}-0.013 \\
(0.01)\end{array}$ & $\begin{array}{l}0.006 \\
(0.01)\end{array}$ & $\begin{array}{l}0.005 \\
(0.01)\end{array}$ \\
\hline worker share & $\begin{array}{l}0.078^{\star *} \\
(0.04)\end{array}$ & $\begin{array}{l}0.049^{*} \\
(0.03)\end{array}$ & $\begin{array}{l}0.022 \\
(0.04)\end{array}$ & $\begin{array}{l}0.077^{\star *} \\
(0.04)\end{array}$ & $\begin{array}{l}0.044 \\
(0.03)\end{array}$ & $\begin{array}{l}0.024 \\
(0.04)\end{array}$ & $\begin{array}{l}0.074^{\star \star} \\
(0.04)\end{array}$ & $\begin{array}{l}0.043 \\
(0.03)\end{array}$ & $\begin{array}{l}0.021 \\
(0.04)\end{array}$ \\
\hline Customs law & $\begin{array}{l}-0.021^{* * *} \\
(0.01)\end{array}$ & $\begin{array}{l}-0.014^{* * *} \\
(0.004)\end{array}$ & - & $\begin{array}{l}-0.021^{* * *} \\
(0.01)\end{array}$ & $\begin{array}{l}-0.015^{\star * *} \\
(0.004)\end{array}$ & - & $\begin{array}{l}-0.021^{* * *} \\
(0.01)\end{array}$ & $\begin{array}{l}-0.014^{* * *} \\
(0.004)\end{array}$ & - \\
\hline Investment law & - & - & $\begin{array}{l}0.003 \\
(0.01)\end{array}$ & - & - & $\begin{array}{l}0.003 \\
(0.01)\end{array}$ & - & - & $\begin{array}{l}0.003 \\
(0.01)\end{array}$ \\
\hline Advertise & - & - & $\begin{array}{l}0.012 \\
(0.02)\end{array}$ & - & - & $\begin{array}{l}0.014 \\
(0.02)\end{array}$ & - & - & $\begin{array}{l}0.013 \\
(0.02)\end{array}$ \\
\hline $\begin{array}{l}\text { New prod. } \\
\text { introduction }\end{array}$ & $\begin{array}{l}-0.026 \\
(0.03)\end{array}$ & $\begin{array}{l}-0.027^{*} \\
(0.01)\end{array}$ & $\begin{array}{l}-0.013 \\
(0.03)\end{array}$ & - & - & - & - & - & - \\
\hline $\begin{array}{l}\text { Old prod. } \\
\text { improvement }\end{array}$ & - & - & - & $\begin{array}{l}0.017 \\
(0.01)\end{array}$ & $\begin{array}{l}0.012 \\
(0.01)\end{array}$ & $\begin{array}{l}-0.018 \\
(0.01)\end{array}$ & - & - & - \\
\hline $\begin{array}{l}\text { Mew process } \\
\text { adoption }\end{array}$ & - & - & - & - & - & - & $\begin{array}{l}-0.007 \\
(0.01)\end{array}$ & $\begin{array}{l}-0.0003 \\
(0.01)\end{array}$ & $\begin{array}{l}-0.012 \\
(0.02)\end{array}$ \\
\hline$\rho$ & $\begin{array}{l}0.87 \\
(0.03)\end{array}$ & $\begin{array}{l}0.88 \\
(0.05)\end{array}$ & $\begin{array}{l}0.42 \\
(0.06)\end{array}$ & $\begin{array}{l}0.86 \\
(0.03)\end{array}$ & $\begin{array}{l}0.86 \\
(0.05)\end{array}$ & $\begin{array}{l}0.42 \\
(0.06)\end{array}$ & $\begin{array}{l}0.87 \\
(0.03)\end{array}$ & $\begin{array}{l}0.87 \\
(0.05)\end{array}$ & $\begin{array}{l}0.42 \\
(0.06)\end{array}$ \\
\hline $\begin{array}{l}\text { Log } \\
\text { pseudolikelihood }\end{array}$ & -458.5 & -248.1 & -778.7 & -457.6 & -248.3 & -777.9 & -458.9 & -249.6 & -778.6 \\
\hline $\begin{array}{l}\text { Wald chi-sq } \\
\text { No. of } \\
\text { enterprises } \\
\text { No. of } \\
\text { observations }\end{array}$ & $\begin{array}{l}89.9^{* * *} \\
1,221 \\
2,442\end{array}$ & $\begin{array}{l}38 \cdot 1^{* \star *} \\
1,221 \\
2,442\end{array}$ & $\begin{array}{l}70.1^{* * *} \\
1,221 \\
2,442\end{array}$ & $\begin{array}{l}93.8^{\star \star *} \\
1,221 \\
2,442\end{array}$ & $\begin{array}{l}43.5^{\star \star *} \\
1,221 \\
2,442\end{array}$ & $\begin{array}{l}70.8^{\star * *} \\
1,221 \\
2,442\end{array}$ & $\begin{array}{l}89.9^{* * *} \\
1,221 \\
2,442\end{array}$ & $\begin{array}{l}44.2^{\star \star *} \\
1,221 \\
2,442\end{array}$ & $\begin{array}{l}72.4^{\star \star *} \\
1,221 \\
2,442\end{array}$ \\
\hline
\end{tabular}

Notes: Sample: balanced panel. Numbers in parentheses are standard errors calculated using the delta method. Regressions include a complete set of time, location, industry, and ownership type qualitative indicators. The standard errors are calculated using the delta method. ${ }^{* * *},{ }^{* *},{ }^{*}$ statistically significant at the $1,5,10$ per cent level.

Source: 2011, 2013, and 2015 Survey of Small and Medium Scale Manufacturing Enterprises (SMEs) in Viet Nam (UNU-WIDER et al. various years).

Since a large amount of information is lost using the lagged specification, we also provide marginal effects for the contemporaneous version of the model in Table 7 but keeping in mind the tentative nature of conclusions based on these results. Recall that the propensity to export and work as subcontractor are associated with contemporaneous technical capacity. Specifically, new product and new process/technology introductions increase the likelihood of exporting (broad definition) 
by 0.03 , ceteris paribus. These marginal effects appear small, but considering that only 8.4 per cent (0.084) of the MSMEs in the sample export, these marginal effects, in fact, are economically meaningful. Since only 11 per cent (0.11) are subcontractors in the sample, a marginal effect of 0.04 in the subcontracting equation for enterprises with improved versions of existing products or have adopted a new process/technology is economically important. Consider these counterfactuals. First, the (average) probability of exporting (broad definition) is estimated to be 0.107 (0.014) and 0.106 (0.011) if all MSMEs were to introduce new products or adopt a new process/technology, respectively_about a 3 percentage point increase in exporting probability overall. Second, the importance of new product introductions to the exporting decision is made more evident in the differences in the actual probability to export of $0.073(0.006)$ with a counterfactual (average predicted) probability to export of 0.107 (0.015) when new product $=0$ are all replaced with $1 \mathrm{~s}$. The probability estimates for new process/technology adoption are 0.069 (0.006) and $0.102(0.011)$, respectively for the actual probability to export and its counterfactual (i.e. when new process $=0$ and all replaced with 1s). Third, if all MSMEs introduce improved versions of existing products, the (average) propensity to produce as subcontractor is estimated to be 0.140 (0.011) — about a 4 percentage point increase in subcontracting probability overall. Fourth, actual and predicted counterfactual probabilities to produce as subcontractors are $0.094(0.006)$ and 0.134 (0.012), respectively when improvements on existing products are made. 
Table 7: Average marginal effects using single-equation random effects probit model, contemporaneous

\begin{tabular}{|c|c|c|c|c|c|c|c|c|c|}
\hline & \multicolumn{3}{|l|}{ (1) } & \multicolumn{3}{|l|}{ (2) } & \multicolumn{3}{|l|}{ (3) } \\
\hline & $\exp$ & direct & subc & $\exp$ & direct & subc & $\exp$ & direct & subc \\
\hline Assets (log) & $\begin{array}{l}0.014^{* \star *} \\
(0.004)\end{array}$ & $\begin{array}{l}0.010^{* * *} \\
(0.003)\end{array}$ & $\begin{array}{l}0.016^{* * *} \\
(0.01)\end{array}$ & $\begin{array}{l}0.014^{* * *} \\
(0.004)\end{array}$ & $\begin{array}{l}0.009^{* * *} \\
(0.003)\end{array}$ & $\begin{array}{l}0.016^{\star * *} \\
(0.01)\end{array}$ & $\begin{array}{l}0.014^{* * *} \\
(0.004)\end{array}$ & $\begin{array}{l}0.009^{* * *} \\
(0.003)\end{array}$ & $\begin{array}{l}0.016^{\star * *} \\
(0.01)\end{array}$ \\
\hline $\begin{array}{l}\text { Labour } \\
\text { productivity (log) }\end{array}$ & $\begin{array}{l}0.005 \\
(0.01)\end{array}$ & $\begin{array}{l}0.002 \\
(0.01)\end{array}$ & $\begin{array}{l}-0.005 \\
(0.01)\end{array}$ & $\begin{array}{l}0.006 \\
(0.01)\end{array}$ & $\begin{array}{l}0.003 \\
(0.01)\end{array}$ & $\begin{array}{l}-0.005 \\
(0.01)\end{array}$ & $\begin{array}{l}0.005 \\
(0.01)\end{array}$ & $\begin{array}{l}0.002 \\
(0.01)\end{array}$ & $\begin{array}{l}-0.005 \\
(0.01)\end{array}$ \\
\hline $\begin{array}{l}\text { Cash flow-to- } \\
\text { asset ratio }\end{array}$ & $\begin{array}{l}0.037 \\
(0.03)\end{array}$ & $\begin{array}{l}0.003 \\
(0.02)\end{array}$ & $\begin{array}{l}0.053 \\
(0.05)\end{array}$ & $\begin{array}{l}0.038 \\
(0.03)\end{array}$ & $\begin{array}{l}0.003 \\
(0.02)\end{array}$ & $\begin{array}{l}0.054 \\
(0.05)\end{array}$ & $\begin{array}{l}0.041 \\
(0.03)\end{array}$ & $\begin{array}{l}0.005 \\
(0.02)\end{array}$ & $\begin{array}{l}0.053 \\
(0.05)\end{array}$ \\
\hline Wages (log) & $\begin{array}{l}0.003 \\
(0.01)\end{array}$ & $\begin{array}{l}0.00007 \\
(0.01)\end{array}$ & $\begin{array}{l}0.011 \\
(0.01)\end{array}$ & $\begin{array}{l}0.004 \\
(0.01)\end{array}$ & $\begin{array}{l}0.00005 \\
(0.01)\end{array}$ & $\begin{array}{l}0.010 \\
(0.01)\end{array}$ & $\begin{array}{l}0.003 \\
(0.01)\end{array}$ & $\begin{array}{l}0.0004 \\
(0.01)\end{array}$ & $\begin{array}{l}0.011 \\
(0.01)\end{array}$ \\
\hline worker share & $\begin{array}{l}0.094^{* \star \star} \\
(0.03)\end{array}$ & $\begin{array}{l}0.063^{\star \star \star} \\
(0.02)\end{array}$ & $\begin{array}{l}-0.002 \\
(0.03)\end{array}$ & $\begin{array}{l}0.099^{* * *} \\
(0.03)\end{array}$ & $\begin{array}{l}0.064^{\star \star \star} \\
(0.02)\end{array}$ & $\begin{array}{l}-0.004 \\
(0.03)\end{array}$ & $\begin{array}{l}0.098^{\star \star \star} \\
(0.03)\end{array}$ & $\begin{array}{l}0.064^{\star \star \star} \\
(0.02)\end{array}$ & $\begin{array}{l}0.001 \\
(0.03)\end{array}$ \\
\hline Customs law & $\begin{array}{l}-0.019^{\star \star \star} \\
(0.004)\end{array}$ & $\begin{array}{l}-0.016^{\star * \star} \\
(0.003)\end{array}$ & - & $\begin{array}{l}-0.019^{\star \star \star} \\
(0.004)\end{array}$ & $\begin{array}{l}-0.016^{\star \star \star} \\
(0.003)\end{array}$ & - & $\begin{array}{l}-0.018^{\star * *} \\
(0.004)\end{array}$ & $\begin{array}{l}-0.015^{\star \star *} \\
(0.003)\end{array}$ & - \\
\hline Investment law & - & - & $\begin{array}{l}0.012^{*} \\
(0.01)\end{array}$ & - & - & $\begin{array}{l}0.012^{*} \\
(0.01)\end{array}$ & - & - & $\begin{array}{l}0.013^{*} \\
(0.01)\end{array}$ \\
\hline Advertise & - & - & $\begin{array}{l}0.029^{*} \\
(0.02)\end{array}$ & - & - & $\begin{array}{l}0.025 \\
(0.02)\end{array}$ & - & - & $\begin{array}{l}0.028^{*} \\
(0.02)\end{array}$ \\
\hline $\begin{array}{l}\text { New prod. } \\
\text { introduction }\end{array}$ & $\begin{array}{l}0.031^{* * *} \\
(0.01)\end{array}$ & $\begin{array}{l}0.004 \\
(0.01)\end{array}$ & $\begin{array}{l}0.027 \\
(0.02)\end{array}$ & - & - & - & - & - & 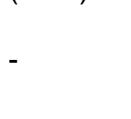 \\
\hline $\begin{array}{l}\text { Old prod. } \\
\text { improvement }\end{array}$ & - & - & - & $\begin{array}{l}0.008 \\
(0.01)\end{array}$ & $\begin{array}{l}0.002 \\
(0.005)\end{array}$ & $\begin{array}{l}0.042^{\star \star \star} \\
(0.01)\end{array}$ & - & - & - \\
\hline $\begin{array}{l}\text { New process } \\
\text { adoption }\end{array}$ & - & - & - & - & - & - & $\begin{array}{l}0.034^{* * *} \\
(0.01)\end{array}$ & $\begin{array}{l}0.015^{\star \star} \\
(0.01)\end{array}$ & $\begin{array}{l}0.039^{*} \\
(0.02)\end{array}$ \\
\hline$\rho$ & $\begin{array}{l}0.89 \\
(0.02)\end{array}$ & $\begin{array}{l}0.87 \\
(0.03)\end{array}$ & $\begin{array}{l}0.33 \\
(0.05)\end{array}$ & $\begin{array}{l}0.88 \\
(0.02)\end{array}$ & $\begin{array}{l}0.87 \\
(0.03)\end{array}$ & $\begin{array}{l}0.34 \\
(0.05)\end{array}$ & $\begin{array}{l}0.89 \\
(0.02)\end{array}$ & $\begin{array}{l}0.87 \\
(0.04)\end{array}$ & $\begin{array}{l}0.33 \\
(0.05)\end{array}$ \\
\hline $\begin{array}{l}\text { Log } \\
\text { pseudolikelihood }\end{array}$ & -526.1 & -253.4 & $-1,119.5$ & -529.3 & -253.5 & $-1,114.7$ & -525.0 & -251.1 & $-1,118.5$ \\
\hline $\begin{array}{l}\text { Wald chi-sq } \\
\text { No. of } \\
\text { enterprises } \\
\text { No. of } \\
\text { observations }\end{array}$ & $\begin{array}{l}105.6^{\star * \star} \\
1,189 \\
3,567\end{array}$ & $\begin{array}{l}73.9^{* * *} \\
1,189\end{array}$ & $110.9^{* \star *}$ & $\begin{array}{l}107.3^{\star \star \star} \\
1,189 \\
3,567\end{array}$ & $\begin{array}{l}74.4^{\star \star \star} \\
1,189\end{array}$ & $\begin{array}{l}123.4^{\star \star *} \\
1,189\end{array}$ & $\begin{array}{l}113.1^{* * *} \\
1,189 \\
3,567\end{array}$ & $\begin{array}{l}71.1^{\star \star *} \\
1,189 \\
3,567\end{array}$ & $\begin{array}{l}117.4^{\star \star \star} \\
1,189 \\
3,567\end{array}$ \\
\hline
\end{tabular}

Notes: Sample: balanced panel. Numbers in parentheses are standard errors calculated using the delta method. Regressions include a complete set of time, location, industry, and ownership type qualitative indicators, firm size, labour productivity, capital intensity, average wages, and production worker share. The subcontracting equation also includes an advertisement dummy variable. ${ }^{* \star *},{ }^{* *},{ }^{*}$ statistically significant at the $1,5,10$ per cent level.

Source: 2011, 2013, and 2015 Survey of Small and Medium Scale Manufacturing Enterprises (SMEs) in Viet Nam (UNU-WIDER et al. various years).

\section{Competitiveness}

As previously mentioned, a comprehensive approach to SME development was put in place in 2009 not only to increase the contribution of MSMEs to Viet Nam's total output, but also to make them competitive. In this section, we tackle three competitiveness indicators: mark-ups, market concentration, and growth in firm size. 


\subsection{Mark-ups}

Similar to other developing economies, Viet Nam's private sector is comprised mostly of microand small-sized enterprises (Ministry of Planning and Investment 2014). Because of their small size, they are not able to achieve the economies of scale necessary to be competitive. We argue that a necessary condition in making TFP growth the main source of growth again in Viet Nam is for its MSMEs to grow organically in size. One way to achieve economies of scale is through exports or participation in international value chains as subcontractors. To date, we observe limited internationalization of Viet Nam's MSMEs (about 7 per cent are engaged in export in 2011-15), although this is more than double the 3 per cent rate in 2003 (see Kokko and Sjöholm 2005). Although domestic market focused, based on dimensions emphasized by a report from the International Trade Center (2015), is there evidence that MSMEs are ready to compete in terms of scope (i.e. limited but profitable), market coverage (i.e. national versus local), and scale (small but growing)? We deal with the first issue in this sub-section. ${ }^{29}$

Prior studies estimate mark-ups using output (value added or revenue) and input (employment, material usage, and capital stock) data which require strong assumptions on production technology, market structure, and consumer preferences. Recent contributions relax some assumptions. De Loecker and Warzynski's $(2012: 2,468)$ methodology 'accommodate a large class of price-setting models' to obtain heterogeneous firm mark-ups. However, they 'keep demand shocks in the background' Forlani et al. (2016: 3). Forlani et al. (2016) emphasize that firms may face different demand conditions (due to quality differences, for example), which not only lead to different prices but also varying mark-ups. The authors' important contribution is to add demand as a third source of firm heterogeneity (the other two are productivity and mark-ups), and show that for any given level of quantity sold, firms charge very different prices (price might proxy for product quality).

Our approach to obtaining mark-ups is in the tradition of de Mel et al. (2009) and Atkin et al. (2015). Both studies use direct responses to survey questions about profits, prices, and unit production costs to estimate mark-ups. De Mel et al. (2009) identify challenges related to understanding the operations of microenterprises including recall error, personal use of enterprise resources, mismatch in the timing of input purchase and sales, and deliberate under- (over-) reporting of sales (expenses). Relevant for our purposes is their finding that 'direct reports of profits, adjusted for household use of enterprise resources, are likely to be less noisy and at least as reliable as asking firms for all the details of the revenues and expenses' (de Mel et al. 2009: 20). Thus, one can be reasonably confident on profits calculated from reported per unit prices and costs. The authors find that mark-ups tend to increase with sales (with an elasticity estimate of 0.13). But we do need to be circumspect in using mark-ups based on reported sales and costs as the authors observe a median profit under-reporting rate of about 32 per cent for the Sri Lanka microenterprises in their study. Atkin et al. (2015) study the operations of soccer ball producers in Pakistan. They find that mark-ups and costs increase with firm size (using employment, this is a proxy for entrepreneurial ability). Larger firms charge higher mark-ups because they produce a larger share of higher-quality items. Their costs are higher because they use higher-quality inputs to produce. They also find that mark-ups are correlated with marketing activities.

Our dataset contains price, cost per unit, and quantity produced and sold at the 4-digit Viet Nam Standard Industrial Classification (VSIC) level. We focus on each enterprise's most important

\footnotetext{
29 Throughout section 3, we include enterprises with at least two years of data in our estimates to partly mitigate problems associated with survivor bias.
} 
product (i.e. 4-digit VSIC code). ${ }^{30}$ Data show a median mark-up rate of 19-22 per cent, and there is no difference in the median mark-ups among exporters and non-exporters, and among subcontractors and independent operators. As a prelude to understanding mark-ups, we first establish the extent of demand heterogeneity. Demand heterogeneity for select products is apparent in Figure 1 where prices vary for any given level of quantity sold. ${ }^{31}$ Survey responses indicate no form of government involvement in MSMEs' price-setting strategy. Mark-ups vary as well, but they are weakly correlated with either price or cost. Figure 2 provides the mark-up densities for select items as examples. Mark-up densities are either 'flat' in some wide range (e.g. machining), or unimodal (e.g. bakery items or apparel), or bimodal (e.g. furniture). There is a slight increase in the proportion of enterprises earning larger mark-ups in the 2015 survey.

Figure 1: Price and quantity sold (demand heterogeneity)
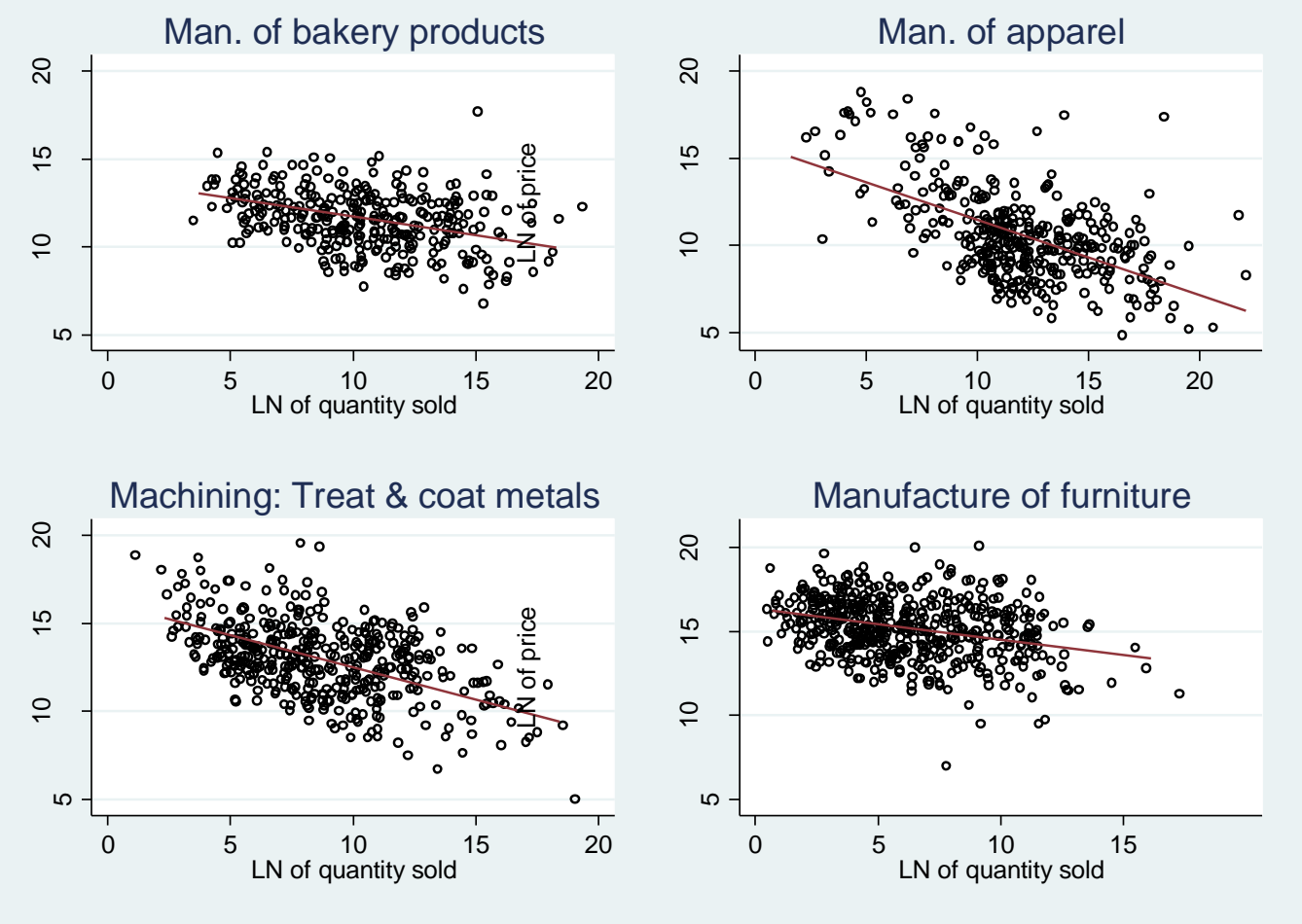

Source: Authors' calculations using data from the 2011, 2013, and 2015 Survey of Small and Medium Scale Manufacturing Enterprises (SMEs) in Viet Nam (UNU-WIDER et al. various years).

30 VSIC (2007 version) is based on the International Standard Industrial Classification revision 4 (ISIC Rev. 4). Admittedly, at the 4-digit VSIC level, there is still much (unobserved) product heterogeneity that could explain markup variations across firms. For example, VSIC 1050 is manufacture of dairy products while VSIC 1071 is manufacture of bakery products. We might not be able to explain mark-up variations across bakery items, but we could between milk products and bread products.

31 These are 4 of the 9 VSIC codes with at least 70 enterprises in operation in each of the three survey years. 
Figure 2: Distribution of mark-ups for select industries
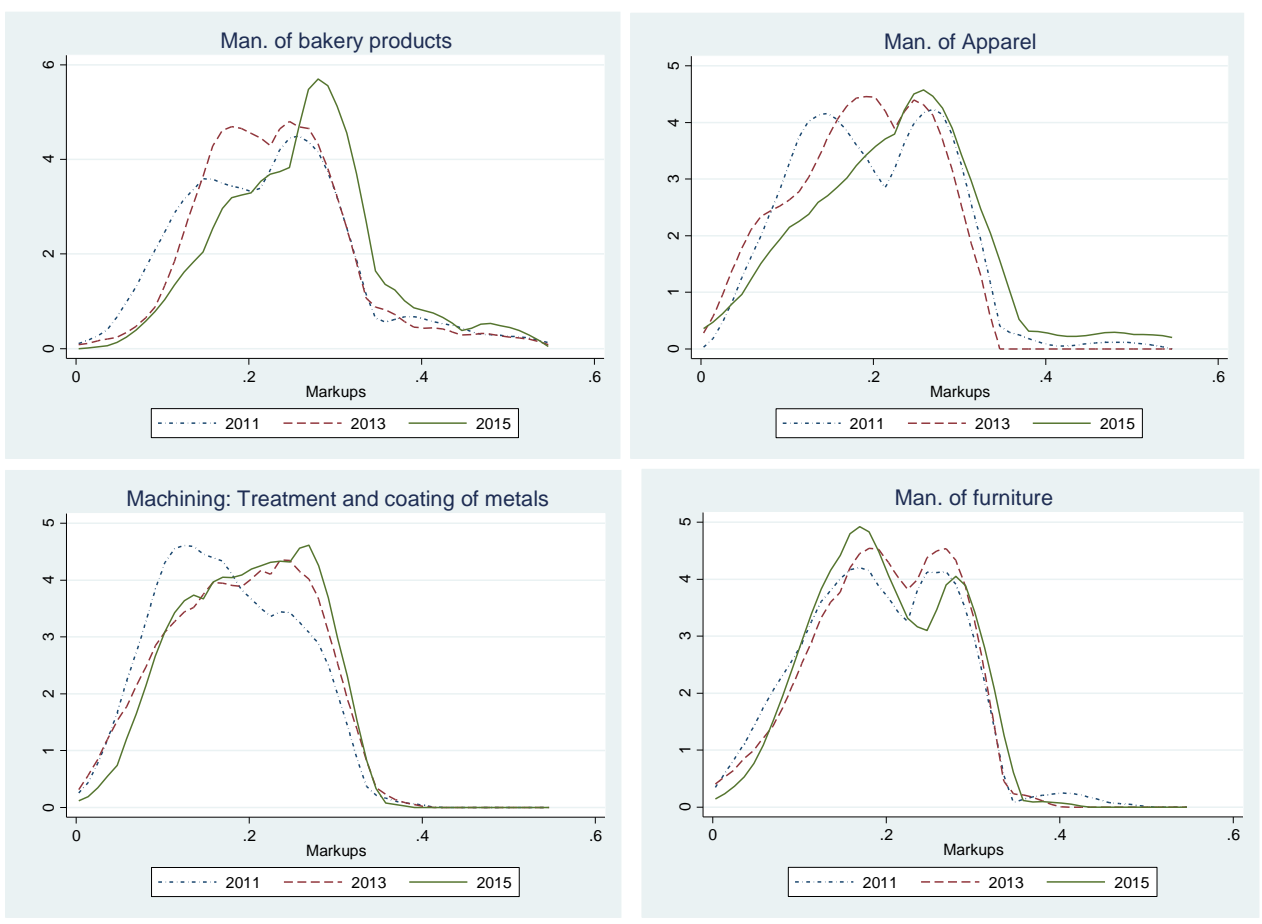

Source: Authors' calculations using data from the 2011, 2013, and 2015 Survey of Small and Medium Scale Manufacturing Enterprises (SMEs) in Viet Nam (UNU-WIDER et al. various years).

Viet Nam's more open environment might lead to higher margins as MSMEs pay lower import tariffs or choose from a larger number of varieties of imported inputs. But, on average, less than 2 per cent of MSMEs' inputs are sourced abroad, and less than 2 per cent of the enterprises source their main equipment from abroad. Global integration might also lead to stiffer competition from import substitutes - thus, lower margins. Responses to the 2013 and 2015 surveys indicate insignificant competitive pressure from imports. Although Viet Nam's MSMEs have not felt competitive pressures from imports, they have also not benefited from the availability of a wider range and potentially better quality inputs or machinery from abroad.

Taking the MSMEs' domestic-market orientation as given, we investigate the correlates to their mark-ups. Our basic specification is based on Atkin et al. (2015) wherein mark-ups is regressed against firm size (employment), an indicator of whether the enterprise advertises, enterprisespecific fixed effects, and full sets of location-year and industry-year interaction dummy variables. According to the literature, mark-ups increase with size because the proportion of higher-quality items increases with enterprise size (e.g. Atkin et al. 2015) or because of economies of scale. We augment this basic specification with an indicator of whether the enterprise has internationally recognized quality certifications and perceived competitive pressure from imports or other entities (such as non-state enterprises). Certifications signal enterprises' commitment to quality products, so we expect mark-ups to be higher for those with internationally recognized quality certificates. Endogeneity between mark-ups and certification (i.e. MSMEs with higher mark-ups are more likely to get certified) while certainly possible is highly unlikely. This is because international certifications, such as ISO 9000, require enterprises to 'adopt and document extensive quality assurance management systems that require nontrivial investments' in resources and time, and third-party audits are required for certification (Potoski and Prakash 2009: 222). For ISO 9000, the process can easily take a year, and certification audits are necessary every three years. Thus, we are quite confident in our use of contemporaneous certification status in the mark-up equation. Current mark-up is a function of whether an MSME currently holds an internationally recognized 
quality certification. Moreover, because certification is not permanent, in some cases, past certification status (measured with a lag of two years in our dataset) might have expired when evaluating current mark-ups.

MSMEs responding 'yes' to facing competition are expected to have lower mark-ups. As a robust check, we use as alternative the proportion of enterprises (producing the same product in the enterprise's home province) responding 'yes' to facing competition (peer-assessment of competition). The 2013 and 2015 surveys also ask the level of competitive pressure from various groups (e.g. state-owned enterprises (SOEs), non-state enterprises, and legal imports) with responses varying from 1 to 4 (where 1 is severe competition; 2 is moderate; 3 is insignificant; and 4 is no competition). We use both self- and peer-assessment of competitive pressures. For the most part, 88 per cent report facing competition, $60-75$ per cent indicate severe to moderate competition from other non-state enterprises, and less than one-third report these levels of competition from other entities.

Table 8 contains the mark-ups fixed effects panel regression results. The models have an overall fit of 3-5 per cent. In all specifications, at the 10 per cent level of significance, we find that larger enterprises have lower mark-ups. Enterprises compete in the price-quality space, and price is an imperfect proxy for quality. Input quality contributes to output (product) quality. Recall Atkin et al.'s (2015) argument that larger firms charge higher prices because a larger proportion of sales is higher-quality items. Costs also increase with size because larger firms use better quality inputs. A positive correlation between size and mark-up is then indicative of larger firms having better management reflected in higher differentials between output prices and input costs (higher-quality premium for larger firms). Our data show a positive correlation between size and price (cost), but size and mark-ups are inversely related, indicative of lower quality premiums for larger enterprises in Viet Nam. Thus, based on Atkin et al.'s (2015) arguments, smaller Vietnamese MSMEs appear to have better management since they earn higher mark-ups.

In regressions including 2011 survey data, there is no evidence that mark-ups are correlated with whether an enterprise has a certification, ${ }^{32}$ faces competitive pressures, or spends on advertising. The importance of having an internationally recognized quality certification or advertising spending are apparent only in regressions using data from the 2013 and 2015 surveys. At the 5 per cent level of significance, certifications boost mark-ups by 2 percentage points; a similar increase in mark-ups is estimated if an enterprise advertises. For an MSME with a median mark-up rate (around 20 per cent), these suggest a significant boost in mark-ups. Interestingly, although a large proportion indicate facing competition (85 per cent), mark-ups do not appear to vary with self- or peer-assessment of competitive pressures from any entity (SOE, other private non-state enterprises, or imports). ${ }^{33}$

\footnotetext{
${ }^{32}$ The certification variable is significantly different from zero at the 11 per cent level of significance.

${ }^{3}$ When lagged internationally recognized certification status is used, the coefficient becomes negative and statistically significant at the 10 per cent level for some specifications. This highlights the importance of keeping certification status current.
} 
Table 8: Panel fixed effects: mark-ups regressions

\begin{tabular}{|c|c|c|c|c|c|c|c|}
\hline \multirow[t]{3}{*}{ Variables } & \multicolumn{2}{|c|}{ All survey years } & \multicolumn{5}{|c|}{ Survey years: 2013 and 2015 only } \\
\hline & Self & Peer & Self & Peer & Self & Self & Self \\
\hline & Spec. (1) & Spec. (2) & Spec. (1) & Spec. (2) & Spec. (3) & Spec. (4) & $\begin{array}{l}\text { Spec. } \\
\text { (5) }\end{array}$ \\
\hline $\begin{array}{l}\text { Initial employ. } \\
\text { (log) }\end{array}$ & $\begin{array}{l}-0.012^{* * *} \\
(0.003)\end{array}$ & $\begin{array}{l}-0.012^{\star \star \star} \\
(0.003)\end{array}$ & $\begin{array}{l}-0.008^{*} \\
(0.005)\end{array}$ & $\begin{array}{l}-0.008^{*} \\
(0.005)\end{array}$ & $\begin{array}{l}-0.008^{\star} \\
(0.005)\end{array}$ & $\begin{array}{l}-0.008^{*} \\
(0.005)\end{array}$ & $\begin{array}{l}-0.008^{*} \\
(0.005)\end{array}$ \\
\hline Certifications & $\begin{array}{l}0.011^{+} \\
(0.007)\end{array}$ & $\begin{array}{l}0.011^{+} \\
(0.007)\end{array}$ & $\begin{array}{l}0.023^{* *} \\
(0.011)\end{array}$ & $\begin{array}{l}0.022^{* *} \\
(0.011)\end{array}$ & $\begin{array}{l}0.023^{* *} \\
(0.011)\end{array}$ & $\begin{array}{l}0.023^{* *} \\
(0.011)\end{array}$ & $\begin{array}{l}0.023^{* *} \\
(0.011)\end{array}$ \\
\hline Competition (yes) & $\begin{array}{l}-0.004 \\
(0.004)\end{array}$ & $\begin{array}{l}0.003 \\
(0.009)\end{array}$ & $\begin{array}{l}0.0034 \\
(0.006)\end{array}$ & $\begin{array}{l}0.032^{* *} \\
(0.016)\end{array}$ & - & - & - \\
\hline Competition (soe) & - & - & - & - & $\begin{array}{l}0.0001 \\
(0.002)\end{array}$ & & - \\
\hline $\begin{array}{l}\text { Competition } \\
\text { (private) }\end{array}$ & - & - & - & - & - & $\begin{array}{l}0.0020 \\
(0.002)\end{array}$ & - \\
\hline $\begin{array}{l}\text { Competition } \\
\text { (imports) }\end{array}$ & - & - & - & - & - & - & $\begin{array}{l}0.0008 \\
(0.002)\end{array}$ \\
\hline Advertises & $\begin{array}{l}0.006 \\
(0.005)\end{array}$ & $\begin{array}{l}0.006 \\
(0.005)\end{array}$ & $\begin{array}{l}0.018^{* *} \\
(0.007)\end{array}$ & $\begin{array}{l}0.018^{* *} \\
(0.007)\end{array}$ & $\begin{array}{l}0.018^{* *} \\
(0.007)\end{array}$ & $\begin{array}{l}0.018^{* *} \\
(0.007)\end{array}$ & $\begin{array}{l}0.018^{* *} \\
(0.007)\end{array}$ \\
\hline R-square: & & & & & & & \\
\hline within & 0.06 & 0.06 & 0.11 & 0.11 & 0.11 & 0.11 & 0.11 \\
\hline between & 0.06 & 0.06 & 0.02 & 0.02 & 0.02 & 0.03 & 0.03 \\
\hline overall & 0.05 & 0.05 & 0.03 & 0.03 & 0.03 & 0.03 & 0.03 \\
\hline $\begin{array}{l}\text { No. of enterprises } \\
\text { No. of } \\
\text { observations }\end{array}$ & $\begin{array}{l}2,349 \\
6,215\end{array}$ & $\begin{array}{l}2,349 \\
6,215\end{array}$ & $\begin{array}{l}1,500 \\
3,100\end{array}$ & $\begin{array}{l}1,500 \\
3,100\end{array}$ & $\begin{array}{l}1,550 \\
3,100\end{array}$ & $\begin{array}{l}1,550 \\
3,100\end{array}$ & $\begin{array}{l}1,550 \\
3,100\end{array}$ \\
\hline
\end{tabular}

Notes: Clustered (by enterprise) standard errors in parentheses. Panel regressions include a constant term, enterprise-specific fixed effects, and complete sets of location-year and industry-year interaction dummy variables. ${ }^{* *},{ }^{* *},{ }^{*}$ statistically significant at the $1,5,10$ per cent level. ${ }^{+}$statistically significant at the 11 per cent level.

Source: 2011, 2013, and 2015 Survey of Small and Medium Scale Manufacturing Enterprises (SMEs) in Viet Nam (UNU-WIDER et al. various years).

\subsection{Market concentration}

Despite the economy's relative openness, Viet Nam's MSMEs are still not well integrated to the global economy. Based on sales of their most important product, MSMEs are not only domesticmarket oriented, their activities are highly localized. The market reach of the MSMEs is limited to their home province. Data show a median share of 100 per cent for sales in the home province (with median shares of 15 and 60 per cent for sales in the home commune and home district, respectively). A similar pattern is observed for the MSMEs' source of inputs. These suggest difficulty in reaching markets beyond one's home province for half of the MSMEs. A similar home (state) bias is observed for the United States at the state level. Using 1993 Commodity Flow Survey data, Wolf (2000) finds within-state shipments were more than 60 per cent of total shipments for several states (e.g. Florida and California). Coughlin and Novy (2013) also find home (state) bias, and conclude that barriers to trade across state lines is larger compared to barriers to trade across the US border. The authors attribute home (state) bias to informational barriers or agglomeration economies. Thus, home market bias is not limited to Viet Nam, but compared to the United States, the size of the home market bias is larger in Viet Nam. 
Motivated by the intranational trade literature, we investigate four issues related to MSMEs' market reach. First, is there evidence supporting the common belief that MSMEs' smallness limits their market reach to their locale (home province)? Second, there is extensive literature that membership in business associations or participation in business networks is potentially advantageous (e.g. Coughlin and Novy 2013). Business networks might provide leads for market expansion beyond enterprises' home province. Understanding their role in market reach is crucial as new market identification is a major problem for about a quarter of the surveyed MSMEs with expansion plans, and only about 8 per cent of the enterprises belong to at least one business association (association membership is set to 1 for membership in at least one business association). Do we observe a larger share of sales outside of the home province for enterprises belonging to at least one business association?

Third, internationally recognized quality certifications, such as ISO 9000, signal commitment to quality production to customers who otherwise have limited or no information about the enterprise. An enterprise's reputation is more likely to be known by customers located in the same commune, district, or province than by those located in other provinces or abroad, so having an internationally recognized quality certification could potentially expand an MSME's market reach beyond its home market. Certifications is set equal to 1, for enterprises holding at least one of these certifications. Among the surveyed MSMEs, 6 per cent have internationally recognized quality certifications, and even those that do not export have these certifications.

Fourth, highly localized sales might be due to agglomeration economies (e.g. to reap benefits from proximity to customers and suppliers). As described by Coughlin and Novy (2013), localization could be due to producers locating close to their customers, or producers agglomerating close to input suppliers. Available data allow us to investigate these two issues indirectly using each enterprise's production structure ${ }^{34}$ (percentage of production used for final consumption) and proportion of inputs sourced from the home province. Controlling for inputs sourced locally, a positive coefficient for the overall production structure (in regressions with sales concentration at the home commune, home district, and home province as dependent variable) suggests home market bias due to proximity to final customers. Given the production structure, a negative coefficient for the share of home province input sourcing is indicative of home market bias due to proximity to input suppliers. All regressions include enterprise-specific fixed effects and full sets of industry-year and location-year interaction dummy variables. Respectively, these account for unobserved heterogeneity at the enterprise level, location-year variations in concentrations due to changes in each location's income or transport infrastructure quality, and industry-year variations in concentrations due to changes specific to each industry.

Table 9 contains the fixed effects panel regression results. Estimates using home commune, home district, and home province shares to total sales as dependent variable are in columns (1) to (3), respectively. Overall R-square is decent at 0.13-0.27. Larger MSMEs have lower home (commune, district, and province) market sales. There is no evidence that business network membership contributes to variations in commune and district sales, but membership boosts non-home province sales (as home province sales are lower by 5 percentage points). Enterprises with at least one internationally recognized quality certification have lower home (commune, district, and province) market sales. This is because international certifications boost sales outside of the home province (home province sales are lower by about 6 percentage points). The positive coefficients for both production structure and share of inputs sourced in the home province indicate home

${ }^{34}$ Unfortunately, we do not know the structure of sales at each location (e.g. district level). 
market bias due to proximity to customers. Home market sales increase with the share of production for final consumption and with the share of inputs sourced in the home province.

Table 9: Panel fixed effects: market concentration regressions

\begin{tabular}{|c|c|c|c|}
\hline \multirow[b]{2}{*}{ Variables } & \multicolumn{3}{|c|}{ Market concentration } \\
\hline & $\begin{array}{l}\text { Home commune } \\
\text { (1) }\end{array}$ & $\begin{array}{l}\text { Home district } \\
(2)\end{array}$ & $\begin{array}{l}\text { Home province } \\
\text { (3) }\end{array}$ \\
\hline \multirow[t]{2}{*}{ Initial employ. (log) } & $-2.318^{\star \star \star}$ & $-3.706^{\star \star \star}$ & $-2.408^{\star *}$ \\
\hline & $(0.82)$ & $(1.03)$ & $(0.93)$ \\
\hline \multirow[t]{2}{*}{ Assoc. memberships } & -1.319 & -2.456 & $-4.683^{\star \star}$ \\
\hline & $(1.29)$ & $(1.70)$ & $(2.08)$ \\
\hline \multirow[t]{2}{*}{ Certifications } & $-1.945^{\star}$ & -2.703 & $-6.482^{\star * \star}$ \\
\hline & $(1.10)$ & $(2.00)$ & $(2.34)$ \\
\hline \multirow[t]{2}{*}{ Production for final cons. } & $0.068^{* * *}$ & $0.102^{* * *}$ & $0.049^{* * *}$ \\
\hline & $(0.01)$ & $(0.01)$ & $(0.01)$ \\
\hline \multirow[t]{2}{*}{ Inputs from home province } & $0.051^{\star * *}$ & $0.091^{* \star *}$ & $0.141^{* * *}$ \\
\hline & $(0.01)$ & $(0.02)$ & $(0.02)$ \\
\hline \multicolumn{4}{|l|}{ R-square: } \\
\hline within & 0.04 & 0.07 & 0.08 \\
\hline between & 0.16 & 0.34 & 0.19 \\
\hline overall & 0.13 & 0.27 & 0.15 \\
\hline No. of enterprises & 2,389 & 2,389 & 2,389 \\
\hline No. of observations & 6,354 & 6,354 & 6,354 \\
\hline
\end{tabular}

Notes: Clustered (by enterprise) standard errors in parentheses. Panel regressions include a constant term, enterprise-specific fixed effects, and complete sets of location-year and industry-year interaction dummy variables. ${ }^{* \star *},{ }^{* *},{ }^{*}$ statistically significant at the $1,5,10$ per cent level.

Source of data: 2011, 2013, and 2015 Survey of Small and Medium Scale Manufacturing Enterprises (SMEs) in Viet Nam (UNU-WIDER et al. various years).

\subsection{Growth in firm size}

Besides employment, prior studies have used total assets and total sales as proxy for firm size. It is important to note that this predilection towards smallness is less pronounced using assets as a measure of firm size (see Figure 3) ${ }^{35}$ For our purposes, some evidence of growth in size would be preliminary evidence of movement towards increased competitiveness. Figure 4 provides the kernel densities of the differences in the natural log of full-time employment, assets, and sales for two survey years while Table 10 contains summary statistics. The median difference in the natural $\log$ of full-time employment is 0 (no growth); a quarter of the enterprises experienced growth (contraction) in employment higher (lower) than 20 per cent (25 per cent) in the 2011-15 period. In real terms $(2005=100)$, assets and sales for more than half of the MSMEs contracted between two survey years.

\footnotetext{
35 Throughout section 3, observations in the top and bottom 1 per cent of the overall distribution for each of the main variables of interest (e.g. employment growth) are omitted to mitigate the influence of outliers.
} 
Figure 3: Kernel density of employment, total assets, and total sales
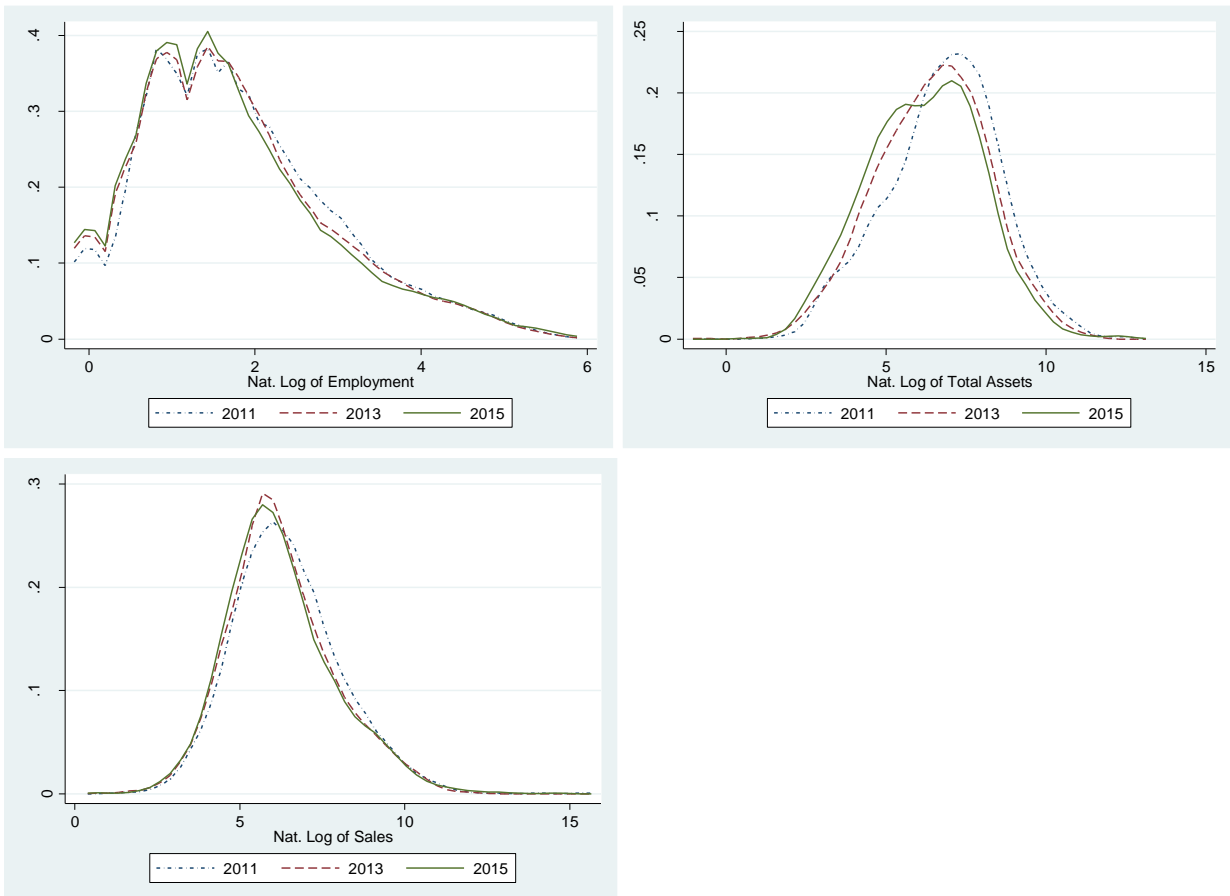

Source: Authors' calculations using data from the 2011, 2013, and 2015 Survey of Small and Medium Scale Manufacturing Enterprises (SMEs) in Viet Nam (UNU-WIDER et al. various years).

Figure 4: Growth in employment, total assets, and total sales
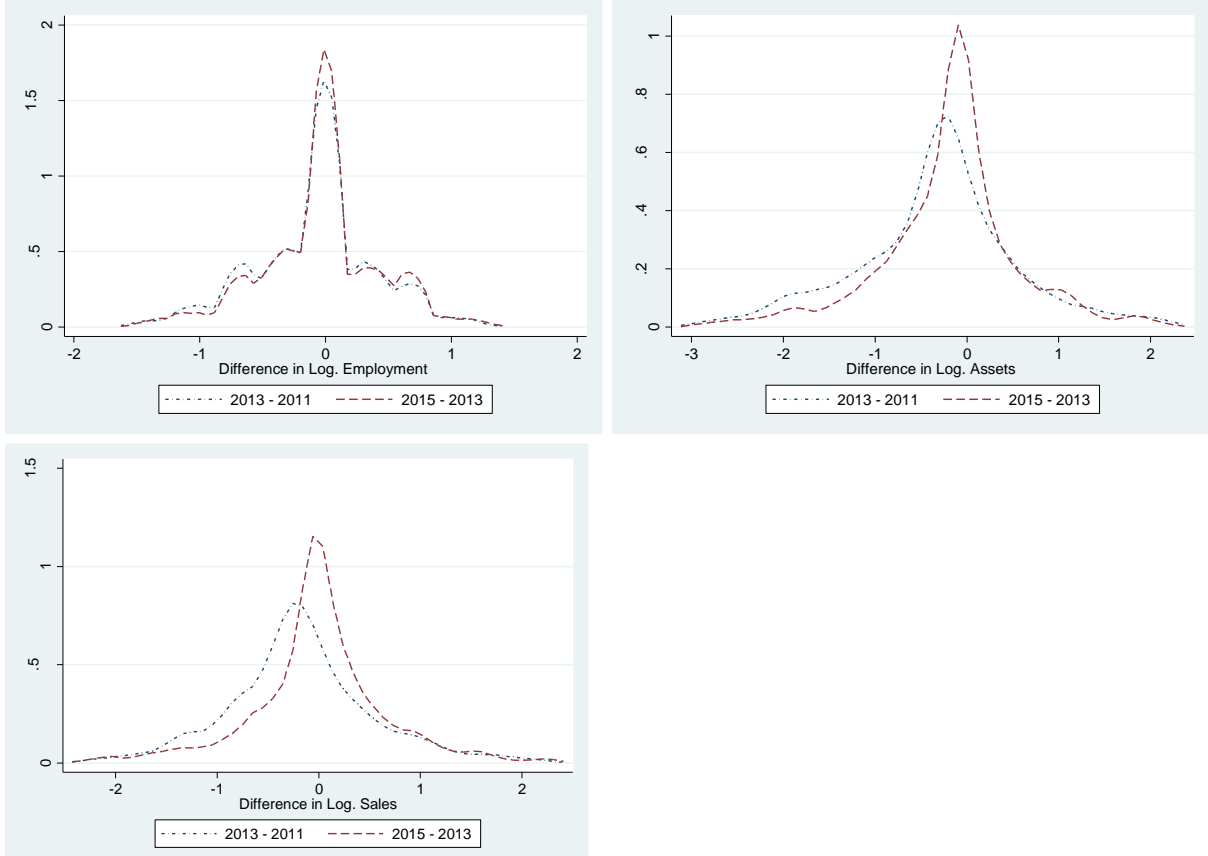

Source: Authors' calculations using data from the 2011, 2013, and 2015 Survey of Small and Medium Scale Manufacturing Enterprises (SMEs) in Viet Nam (UNU-WIDER et al. various years). 
Table 10: Growth rates of full-time employment, total assets, and total sales

\begin{tabular}{|c|c|c|c|c|c|c|}
\hline & \multicolumn{6}{|c|}{ Growth rates } \\
\hline & \multicolumn{2}{|c|}{ Employment } & \multicolumn{2}{|c|}{ Total assets } & \multicolumn{2}{|c|}{ Total sales } \\
\hline & 2013-15 & 2011-13 & 2013-15 & 2011-13 & 2013-15 & 2011-13 \\
\hline Mean & -3.43 & -8.26 & -17.22 & -28.41 & -0.62 & -16.24 \\
\hline Std Dev. & 58.71 & 61.65 & 112.34 & 140.11 & 94.67 & 105.42 \\
\hline Obs. & 2,010 & 1,934 & 2,045 & 1,947 & 1,995 & 1,895 \\
\hline Min & -78.95 & -79.49 & -94.76 & -95.10 & -90.39 & -89.59 \\
\hline 10th perc. & -50.00 & -50.00 & -66.19 & -78.25 & -53.71 & -64.89 \\
\hline 25th perc. & -25.00 & -33.33 & -40.58 & -54.22 & -24.62 & -43.73 \\
\hline Median & 0.00 & 0.00 & -11.20 & -23.55 & -1.35 & -18.12 \\
\hline 75th perc. & 20.00 & 14.29 & 13.81 & 11.86 & 32.27 & 19.61 \\
\hline 90th perc. & 84.52 & 66.67 & 96.73 & 102.16 & 121.42 & 113.76 \\
\hline Max & 288.89 & 275.00 & 868.05 & 868.68 & 921.92 & 902.69 \\
\hline
\end{tabular}

Source: 2011, 2013, and 2015 Survey of Small and Medium Scale Manufacturing Enterprises (SMEs) in Viet Nam (UNU-WIDER et al. various years).

Some argue that the bias towards smallness can be explained by 'fear of growth' as growth attracts the attention of corrupt officials demanding bribe payments, or puts the enterprise at risk of unwarranted repeated inspections for compliance with say tax, labour, or environmental regulations. ${ }^{36}$ The survey asks the number of times the enterprise was inspected by government officials for policy compliance (e.g. labour and tax regulations) and for technical compliance (e.g. environment and fire regulations). An inverse relationship between growth and the (lagged) number of compliance inspections would be consistent with the 'fear-of-growth' hypothesis. Following Ayyagari et al. (2016), we also control for initial size, age, home market bias, (lagged) financial constraint (constrained2, as defined in section 2), enterprise-specific fixed effects, and full sets of location-year and industry-year interaction dummy variables in the growth regressions. Haltiwanger et al. (2013) emphasize the importance of controlling for both firm size and age in employment growth regressions. Using 1992-2005 data from the United States, Haltiwanger et al. (2013: 360) find 'that the inverse relationship between size and employment growth disappears after controlling for firm age'. Controlling for age is crucial as young firms tend to be small, and if young firms do not exit, they tend to grow faster than older firms. Using firm-level data from as many as 104 countries, Ayyagari et al. (2011) find that small firms have higher employment and sales growth compared to medium and large firms, and these correlations hold even after controlling for firm age. Home market bias might also explain enterprise growth. There simply might not be room for growth if MSMEs' markets are limited to their home provinces. We use the residuals (actual minus predicted home province sales share) from the home bias regression in section 3.2 to test this notion. ${ }^{37}$ Since positive (negative) residuals indicate too much (little) home province concentration of sales beyond the model's predictions, a negative coefficient is expected. Overly concentrated sales is expected to lead to zero or low growth. Financially constrained enterprises are expected to achieve no or low growth. All regressors are measured at the start of the relevant growth period. Enterprise-specific fixed effects control for unobserved heterogeneity;

\footnotetext{
36 Officials have incentives to pursue investigations as their performance evaluations are partly based on the number of investigations they handle (Dau 2016).

${ }^{37}$ In the previous subsection, market concentration is found to be associated with initial employment, so it cannot be directly included in the growth regression models as initial size (e.g. employment) is a regressor in these models.
} 
location-year (industry-year) interaction dummies account for growth differences across locations (industries) for each period.

Fixed effects panel regression estimates are provided in Table 11. The models have an overall fit of 4-6 per cent. In all specifications, enterprise size is statistically significant at the 1 per cent level and has a negative coefficient; growth rates are lower for larger enterprises. In particular, a 1-log point difference in size leads to a (negative) 1.2-1.3 log point differential in growth rates. If enterprise size almost doubles (a 1-log point increase is equivalent to a 172 per cent increase), growth is lower by about 70 per cent (a $-1.2 \mathrm{log}$ point is equivalent to a 70 per cent contraction rate). There is no evidence that variations in home market bias, age, and financial status are correlated with enterprise growth. Only employment and sales growth are correlated with the number of inspections. Less than 2 per cent of the enterprises were subjected to compliance inspections and among those inspected, the number of policy (technical) compliance inspections range from 0 to 6 (0 to 10). Policy and technical compliance inspections are statistically significant at the 5 per cent level. Contrary to the 'fear-of-growth' hypothesis, employment and sales increase by about 8 per cent for each additional (lagged) inspection.

A related question is whether plans to start new projects or product lines in the near future is a function of the factors (excluding home market bias) described above. Panel probit coefficient estimates and marginal effects are provided in Table 12. From these, we find that the likelihood of starting new projects or product lines increases with firm size and decreases with age. Planned expansion is higher for financially constrained enterprises. This finding seems counterintuitive at first, but is consistent with the observation that growing enterprises in Viet Nam are financially constrained (Rand 2007). In fact, of the 20 per cent with expansion plans, close to half indicate lack of capital as a major problem, followed by 'lack of market outlet/problems identifying new markets'. The propensity to expand is not correlated with the (lagged) number of policy and technical compliance inspections. Thus, there is no evidence that inspections deter MSMEs from expanding beyond their existing core competencies. 
Table 11: Panel fixed effects: growth regressions

\begin{tabular}{|c|c|c|c|c|c|c|}
\hline \multirow{3}{*}{ Variables } & \multicolumn{6}{|c|}{ Difference in natural log of: } \\
\hline & \multicolumn{2}{|c|}{ Employment } & \multicolumn{2}{|c|}{ Total assets } & \multicolumn{2}{|c|}{ Total sales } \\
\hline & Spec. (1) & Spec. (2) & Spec. (1) & Spec. (2) & Spec. (1) & Spec. (2) \\
\hline $\begin{array}{l}\text { Initial employ. } \\
\text { (log) }\end{array}$ & $\begin{array}{l}-1.3340^{\star * *} \\
(0.0275)\end{array}$ & $\begin{array}{l}-1.3349^{* * *} \\
(0.0274)\end{array}$ & - & - & - & - \\
\hline $\begin{array}{l}\text { Initial assets } \\
(\log )\end{array}$ & - & - & $\begin{array}{l}-1.2162^{\star \star \star} \\
(0.0244)\end{array}$ & $\begin{array}{l}-1.2177^{\star \star \star} \\
(0.0244)\end{array}$ & - & - \\
\hline Initial sales (log) & - & - & - & - & $\begin{array}{l}-1.2388^{* * *} \\
(0.0287)\end{array}$ & $\begin{array}{l}-1.2387^{* * *} \\
(0.0286)\end{array}$ \\
\hline $\begin{array}{l}\text { Home market } \\
\text { bias }\end{array}$ & $\begin{array}{l}-0.0008 \\
(0.0005)\end{array}$ & $\begin{array}{l}-0.0008^{*} \\
(0.0005)\end{array}$ & $\begin{array}{l}-0.0001 \\
(0.0006)\end{array}$ & $\begin{array}{l}-0.0001 \\
(0.0006)\end{array}$ & $\begin{array}{l}0.0002 \\
(0.0006)\end{array}$ & $\begin{array}{l}0.0002 \\
(0.0006)\end{array}$ \\
\hline $\begin{array}{l}\text { Policy } \\
\text { inspections }\end{array}$ & $\begin{array}{l}0.0788^{* *} \\
(0.0373)\end{array}$ & - & $\begin{array}{l}-0.0509 \\
(0.0362)\end{array}$ & - & $\begin{array}{l}0.0699 \\
(0.0436)\end{array}$ & - \\
\hline $\begin{array}{l}\text { Technical } \\
\text { inspections }\end{array}$ & - & $\begin{array}{l}0.0758^{* *} \\
(0.0301)\end{array}$ & - & $\begin{array}{l}0.0123 \\
(0.0251)\end{array}$ & - & $\begin{array}{l}0.0841^{\star *} \\
(0.0350)\end{array}$ \\
\hline Age & $\begin{array}{l}0.0029 \\
(0.0029)\end{array}$ & $\begin{array}{l}0.0029 \\
(0.0029)\end{array}$ & $\begin{array}{l}-0.0016 \\
(0.0047)\end{array}$ & $\begin{array}{l}-0.0017 \\
(0.0047)\end{array}$ & $\begin{array}{l}0.0036 \\
(0.0040)\end{array}$ & $\begin{array}{l}0.0037 \\
(0.0040)\end{array}$ \\
\hline Constrained2 & $\begin{array}{l}-0.0087 \\
(0.0240)\end{array}$ & $\begin{array}{l}-0.0103 \\
(0.0238)\end{array}$ & $\begin{array}{l}0.0087 \\
(0.0354)\end{array}$ & $\begin{array}{l}0.0076 \\
(0.0355)\end{array}$ & $\begin{array}{l}0.0637^{\star} \\
(0.0334)\end{array}$ & $\begin{array}{l}0.0619^{*} \\
(0.0333)\end{array}$ \\
\hline R-square: & & & & & & \\
\hline within & 0.68 & 0.68 & 0.69 & 0.69 & 0.67 & 0.67 \\
\hline between & 0.03 & 0.03 & 0.01 & 0.01 & 0.01 & 0.01 \\
\hline $\begin{array}{l}\text { overall } \\
\text { No. of }\end{array}$ & 0.05 & 0.05 & 0.06 & 0.06 & 0.04 & 0.04 \\
\hline $\begin{array}{l}\text { enterprises } \\
\text { No. of }\end{array}$ & 1,394 & 1,394 & 1,403 & 1,403 & 1,381 & 1,381 \\
\hline
\end{tabular}

Notes: Clustered (by enterprise) standard errors in parentheses. Panel regressions include a constant term, enterprise-specific fixed effects, and complete sets of location-year and industry-year interaction dummy variables. ${ }^{* *},{ }^{* *},{ }^{*}$ statistically significant at the $1,5,10$ per cent level.

Source of data: 2011, 2013, and 2015 Survey of Small and Medium Scale Manufacturing Enterprises (SMEs) in Viet Nam (UNU-WIDER et al. various years). 
Table 12: Panel random effects regressions: plan to start up new projects or product lines

\begin{tabular}{|c|c|c|c|c|c|c|}
\hline \multirow[b]{2}{*}{ Variables } & \multirow[b]{2}{*}{ Mean } & \multirow[b]{2}{*}{ Std. Dev. } & \multicolumn{2}{|c|}{ Coefficients and SE } & \multicolumn{2}{|c|}{ Marginal effects and SE } \\
\hline & & & Spec. (1) & Spec. (2) & Spec. (1) & Spec. (2) \\
\hline Initial employ. (log) & 1.75 & 1.14 & $\begin{array}{l}0.246^{\star \star *} \\
(0.03)\end{array}$ & $\begin{array}{l}0.246^{\star * \star} \\
(0.03)\end{array}$ & $\begin{array}{l}0.066^{\star \star *} \\
(0.01)\end{array}$ & $\begin{array}{l}0.066^{\star \star \star} \\
(0.01)\end{array}$ \\
\hline Policy inspections & 0.04 & 0.30 & $\begin{array}{l}-0.114 \\
(0.09)\end{array}$ & - & $\begin{array}{l}-0.031 \\
(0.03)\end{array}$ & - \\
\hline Technical inspections & 0.04 & 0.35 & - & $\begin{array}{l}-0.071 \\
(0.09)\end{array}$ & - & $\begin{array}{l}-0.019 \\
(0.02)\end{array}$ \\
\hline Age & 15.32 & 7.96 & $\begin{array}{l}-0.002 \\
(0.003)\end{array}$ & $\begin{array}{l}-0.002 \\
(0.003)\end{array}$ & $\begin{array}{l}-0.001 \\
(0.001)\end{array}$ & $\begin{array}{l}-0.001 \\
(0.001)\end{array}$ \\
\hline Constrained2 & 0.19 & 0.38 & $\begin{array}{l}0.160^{* *} \\
(0.07)\end{array}$ & $\begin{array}{l}0.161^{\star *} \\
(0.07)\end{array}$ & $\begin{array}{l}0.043^{* *} \\
(0.02)\end{array}$ & $\begin{array}{l}0.044^{\star *} \\
(0.02)\end{array}$ \\
\hline Log pseudolikelihood & & & $-1,648.30$ & $-1,648.63$ & & \\
\hline Wald chi-sq. & & & $200.35^{\star \star \star}$ & $200.50^{\star \star \star}$ & & \\
\hline No. of enterprises & & & 1,660 & 1,660 & & \\
\hline No. of observations & & & 3,320 & 3,320 & & \\
\hline
\end{tabular}

Notes: Clustered (by enterprise) standard errors in parentheses. Panel regressions include a constant term, complete sets of location-year and industry-year interaction dummy variables. ${ }^{* * *},{ }^{* *},{ }^{*}$ statistically significant at the 1, 5, 10 per cent level.

Source of data: 2011, 2013, and 2015 Survey of Small and Medium Scale Manufacturing Enterprises (SMEs) in Viet Nam (UNU-WIDER et al. various years).

\section{$4 \quad$ Discussion and concluding remarks}

In a short time, Viet Nam has become an important exporter worldwide. It was ranked 32 in 2014 (WTO 2015), but 70.7 per cent of the country's exports in 2015 originated from foreign-invested enterprises (Malesky 2016) while Viet Nam's SMEs only accounted for 20 per cent of exports (International Trade Center 2015). Close to 66 per cent of private sector employment was with SMEs in 2012 (Ministry of Planning and Investment 2014). Given this backdrop, we investigate issues related to MSME participation in export markets, and measures of competitiveness including mark-ups, market concentration, and growth. The export participation rate of Viet Nam's MSMEs in 2010-14 remained low at 6-7 per cent, up from 3 per cent in 2003. We find strong evidence that knowledge of customs law increases the likelihood of exporting. Based on this result, an aggressive informational campaign by government or business associations to increase MSMEs' knowledge of customs law is one approach to eliminating the 'missing middle'. In particular, our counterfactual estimates show that if all MSMEs' knowledge improves from 'poor' to 'good', the probability of exporting increases to 0.150 from 0.074 . Because exporting is hard, the subcontracting route has been touted as an option for MSMEs worldwide (e.g. International Trade Centre 2015). Subcontracting traditionally involves large enterprises. Subcontracting as an option for MSMEs is a much understudied area in the literature. We uncover some evidence that knowledge of investment law increases the likelihood of subcontracting, but this is less clear-cut as the result is sensitive to the sample used in the estimations. There is also some evidence that the likelihood of both exporting and subcontracting are associated with technical capacity, but again these conclusions must remain tentative as they are not robust across samples used. Thus, with some caveats, expanding programmes that enhance the technical capacity of the MSMEs could also potentially eliminate the 'missing middle'. 
Too much competition or unfair competition is a major constraint identified by the MSMEs. The percentage identifying this as the top constraint increased from 20 per cent (2011 survey) to 41 per cent (2015 survey). But, there is no evidence that competitive pressure per se (broadly defined) or variations in self- or peer-assessment of competitive pressures from SOEs, other private enterprises, or from imports are associated with the mark-ups of the MSMEs' most important product. There is some evidence that enterprises with differentiated products earn higher markups, and those with internationally recognized quality certifications earn higher mark-ups as well. Because these certifications are signals of quality, helping MSMEs obtain them would be another way to eliminate the 'missing middle'.

Close to 80 per cent of the MSMEs report insignificant or no competitive pressure from imports and only 3 per cent use imported inputs. This relative 'isolation' from import competition might not be the case for much longer as Viet Nam is party to several bilateral free trade agreements (FTAs) (e.g. with South Korea 2016 and Chile 2014) or as part of its membership in ASEAN (e.g. with India, 2010). These FTAs are also expected to impact how MSMEs source their inputs which could contribute to changing their market reach. In the meantime, current usage of existing FTAs signed by Viet Nam is only 39 per cent, on average (The Economist Intelligence Unit 2014).

MSMEs' sales are highly concentrated in their home provinces. Our results show that MSMEs with internationally recognized quality certifications and which are members of at least one business association have a higher proportion of their sales outside their home province. Thus, one approach to eliminating the 'missing middle' is for policy makers and business groups to help MSMEs find and access markets beyond their provincial borders.

More than half of the MSMEs we studied either did not grow or contracted in size. Close to half indicated shortage of capital as the top growth constraint in 2011, but by the 2015 survey, the rate had dropped to 20 per cent. There is no evidence that home market bias is detrimental to enterprise growth. Financial constraint is statistically insignificant in our growth regressions because access to finance is less important now. We find that financially constrained enterprises are more likely to contemplate starting new projects or new product lines. Together, these results suggest that access to finance does not affect the organic growth of MSMEs, but it does affect expansion plans beyond existing core competencies. Moreover, there is no evidence that compliance inspections deter MSMEs' expansion into new areas. Thus, continued work on access to finance is a necessary step to filling in the 'missing middle'.

Various initiatives on the international front have the potential of helping MSMEs' enter foreign markets. The negative impact of trade costs on MSMEs' ability to engage in trade is magnified. The WTO's Trade Facilitation Agreement (TFA) contains provisions that reduce trade costs. For example, the TFA streamlines customs procedures to expedite the release and clearance of goods; TFA enters into force as two-thirds of WTO's 164 member countries have ratified the agreement. To date, it has been ratified by 106 countries (more than half of the WTO's membership), and Viet Nam is one of these countries (WTO 2017).

At the national level, a draft Law on Supporting SMEs is making its way at the National Assembly (Malesky 2016). This builds on the framework set by past SME Development Plans which aimed to close the gap in the middle of the enterprise size distribution, and to strengthen the capacity of the country's MSMEs to compete as Viet Nam becomes more integrated to the global economy. Not all MSMEs have the capacity to compete internationally. It turns out that a large number are also not competitive beyond their provincial borders. A possible extension to this study is to identify policy biases or regulations at the provincial level limiting access by MSMEs from other areas. The perennial problem of having to pay informal charges to get things done is area specific as well. For example, the ability of MSMEs in Ho Chi Minh City to sell to customers in Long An 
does not only depend on the quality of Ho Chi Minh City's business climate, policies, regulations, or governance quality, but this also depends on Long An's characteristics in these areas.

Another component of trade costs that adversely impact MSMEs disproportionately is the quality of the country's transport and logistics infrastructure. Between 2007 and 2014, according to the World Bank's (2016b) logistics performance index, the quality of Viet Nam's trade and transportrelated infrastructure has improved from 2.5 to 3.1 (where 1 is low quality and 5 is high quality), while the competence and quality of its logistics services improved from 2.8 to 3.1 -both slightly better than the median country. Despite improvements in its transport infrastructure, there is still concern over the poor state of the country's road network. Most freight is still transported via land, and bad roads increase transit time and drive costs up. Given the country's long coast line and river systems, moving freight via sea and river has the potential of lowering transit time and costs (Châu 2014). A second possible extension is to explore variation in transport and logistics infrastructure at the sub-national level and the extent to which these contribute to home market bias observed in the data.

\section{References}

Akyuz, Y. (2011). 'Export Dependence and Sustainability of Growth in China'. China \& World Economy, 19(1): 1-23.

Anderson, J., and D. Sutherland (2015). 'Entry Mode and Emerging Market MNEs: An Analysis of Chinese Greenfield and Acquisition FDI in the United States'. Research in International Business and Finance, 35: 88-103.

Amiti, M., and D. Weinstein (2011). 'Exports and Financial Shocks'. Quarterly Journal of Economics, 126(4): 1841-77.

Atkin, D., A. Chaudhry, S. Chaudry, A.K. Khandelwal, and E. Verhoogen (2015). 'Markup and Cost Dispersion across Firms: Direct Evidence from Producer Surveys in Pakistan'. American Economic Review, 105(5): 537-44.

Ayyagari, M., A. Demirguc-Kunt, and V. Maksimovic (2011). 'Small vs. Young Firms across the World: Contribution to Employment, Job Creation, and Growth'. World Bank Policy Research Working Paper 5631. Washington, DC: The World Bank.

Ayyagari, M., P. Juarros, M.S.M. Peria, and S. Singh (2016). 'Access to Finance and Job Growth: Firm-Level Evidence across Developing Countries’. World Bank Policy Research Working Paper 6704. Washington, DC: The World Bank.

Bandyopadhyay, S., S. Roy, and Y. Liu (2015). 'Contract Enforcement, Corruption Controls and Other Institutions Affect Trade, Too'. The Regional Economist, 23(2): 10-11.

Barone, B., and R. Bendini (2015). 'China: Economic Outlook, 2015'. European Parliament Directorate-General for External Policies Policy Department. Brussels: European Union.

Becker, S.O., and P.H. Egger (2013). 'Endogenous Product Versus Process Innovation and a Firm's Propensity to Export'. Empirical Economics, 44(1): 329-54.

Bellone, F., P. Musso, L. Nesta, and S. Schiavo (2010). 'Financial Constraints and Firm Export Behavior'. The World Economy, 33(3): 347-73.

Bénassy-Quéré, A., M. Coupet, and T. Mayer (2007). 'Institutional Determinants of Foreign Direct Investment'. The World Economy, 30(5): 764-82. 
Berman, N., and J. Héricourt (2010). 'Financial Factors and the Margins of Trade: Evidence from Cross-Country Firm-Level Data'. Journal of Development Economics, 93(2): 206-17.

Bernard, A.B., and J.B. Jensen (2004). 'Why Some Firms Export'. The Review of Economics and Statistics, 86(2): 561-69.

Bich, T. (2016). 'Inefficient Support for SMEs (Hỗ trợ doanh nghiệp vừa và nhỏ chưa hiệu quả)'. In Vietnamese. Available at: http://baodauthau.vn/doanh-nghiep/ho-tro-doanh-nghiepvua-va-nho-chua-hieu-qua-16217.html (accessed 30 August 2016).

Châu, Q.N. (2014). 'Higher Transportation Cost in Vietnam than in US and China (Cước phí vận tải ở Việt Nam cao hơn Mỹ và Trung Quốc)'. In Vietnamese. Available at: http:// dantri.com.vn/xa-hoi/cuoc-phi-van-tai-o-viet-nam-cao-hon-my-va-trung-quoc1416828742.htm (accessed 26 September 2016).

Coughlin, C.C., and D. Novy (2013). 'Is the International Border Effect Larger than the Domestic Border Effect? Evidence from U.S. Trade'. CESifo Economic Studies, 59(2): 249-76.

Dau, T.A. (2016). 'Firms Dare not to Grow (Không dám lớn mạnh)'. In Vietnamese. Available at: http://vnexpress.net/tin-tuc/goc-nhin/khong-dam-lon-manh-3457312.html (accessed 28 August 2016).

De Loecker, J., and F. Warzynski (2012). 'Markups and Firm-Level Export Status'. American Economic Review, 102(6): 2437-71.

de Mel, S., D. McKenzie, and C. Woodruff (2009). 'Measuring Microenterprise Profits: Must we Ask how the Sausage is Made?' Journal of Development Economics, 88(1): 19-31.

Dinh, H.T. (2014). Light Manufacturing in Vietnam: Creating Jobs and Prosperity in a Middle-Income Economy. Washington, DC: The World Bank.

Economist Intelligence Unit, The (2014). 'FTAs in South-East Asia: Towards the Next Generation'. Available at: https://globalconnections.hsbc.com/downloads/ftas_in_southeast_asia.pdf (accessed 12 July 2016).

Esteve-Pérez, S., and D. Rodríguez (2013). 'The Dynamics of Exports and R\&D in SMEs'. Small Business Economics, 41(1): 219-40.

Forlani, E., R. Martin, G. Mion, and M. Muûls (2016). 'Unraveling Firms: Demand, Productivity and Markups Heterogeneity'. CEP Discussion Paper No. 1402. London: Centre for Economic Performance.

Greene, W.H. (2000). Econometric Analysis, Fourth Edition. Upper Saddle River, NJ: Prentice Hall.

Haltiwanger, J., R.S. Jarmin, and J. Miranda (2013). 'Who Creates Jobs? Small Versus Large Versus Young'. The Review of Economics and Statistics, 95(2): 347-61.

Hayashi, M. (2002). 'The Role of Subcontracting in SME Development in Indonesia: Micro-Level Evidence from the Metalworking and Machinery Industry'. Journal of Asian Economics, 10(1): $1-26$.

International Trade Centre (2015). SME Competitiveness Outlook: Connect, Compete and Change for Inclusive Growth. Geneva, Switzerland: International Trade Centre. Available at: http://www.intracen.org/uploadedFiles/intracenorg/2015SMEComp.pdf (accessed 24 September 2016).

Khan, S. (2015). 'Impact of Sources of Finance on the Growth of SMEs: Evidence from Pakistan'. Decision, 42(1): 3-10. 
Kimura. F. (2002). 'Subcontracting and the Performance of Small and Medium Firms in Japan'. Small Business Economics, 18(1): 163-75.

Kokko, A., and F. Sjöholm (2005). 'The Internationalization of Vietnamese Small and MediumSized Enterprises'. Asian Economic Papers, 4(1): 152-77.

Kongmanila, X., and Y. Takahashi. (2009). 'Determinants of Subcontracting in Lao Garment Industry'. Contemporary Management Research, 5(3): 273-86.

Levinsohn, J., and A. Petrin (2003). 'Estimating Production Functions Using Inputs to Control for Unobservables'. The Review of Economic Studies, 70(2): 317-41.

Lin, J.Y., and X. Sun (2006). 'Information, Informal Finance, and SME Financing'. Frontiers of Economics in China, 1(1): 69-82.

Malesky, E. (2016). The Vietnam Provincial Competitiveness Index: Measuring Economic Governance for Private Sector Development, Final Report. Hanoi: Vietnam Chamber of Commerce and Industry and United States Agency for International Development.

Manova, K., and Z. Yu (2015). 'How Firms Export: Processing vs Ordinary Trade with Financial Frictions'. NBER Working Paper 18561. Cambridge, MA: National Bureau of Economic Research

McMillan, J., and C. Woodruff (1999). 'Interfirm Relationships and Informal Credit in Vietnam'. The Quarterly Journal of Economics, 114(4): 1285-320.

Melitz, M.J. (2003). 'The Impact of Trade on Intra-Industry Reallocations and Aggregate Industry Productivity'. Econometrica, 71(6): 1695-725.

Méon, P.-G., and K. Sekkat (2008) 'Institutional Quality and Trade: Which Institutions? Which Trade?' Economic Inquiry, 46(2): 227-40.

Ministry of Planning and Investment (2014). Small and Medium Enterprises in Vietnam: 2014. Hanoi: Agency for Enterprise Development, Ministry of Planning and Investment.

Newman, C., J. Rand, F. Tarp, and A. Nguyen (2014). 'Exporting and Productivity: The Role of Ownership and Innovation in the Case of Vietnam'. WIDER Working Paper 2014/070. Helsinki: UNU-WIDER.

Nguyen, A.N., N.Q. Pham, C.D. Nguyen, and N.D. Nguyen (2008). 'Innovation and Exports in Vietnam's SME Sector'. The European Journal of Development Research, 20(2): 262-80.

OECD and the World Bank (2015). Inclusive Global Value Chains: Policy Options in Trade and Complementary Areas for GVC Integration by Small and Medium Enterprises and Low-Income Developing Countries. Available at: http://www.oecd.org/trade/OECD-WBG-g20-gvc-report-2015.pdf (accessed 24 September 2016)

OECD (2015). Measuring Trade in Value Added: An OECD-WTO Joint Initiative Database. Available at: $\quad$ http://www.oecd.org/sti/ind/measuringtradeinvalue-addedanoecdwtojointinitiative.htm (accessed 5 July 2016).

Plum, A. (2016). 'Bireprob: An Estimator for Bivariate Random-Effects Probit Models'. The Stata Journal, 16(1): 96-111.

Potoski, M., and A. Prakash (2009). 'Information Asymmetries as Trade Barriers: ISO 9000 Increases International Commerce'. Journal of Policy Analysis and Management, 28(2): 221-38.

Rand, J. (2007). 'Credit Constraints and Determinants of the Cost of Capital in Vietnamese Manufacturing'. Small Business Economics, 29(1): 1-13. 
Rauch, J.E. (1999). 'Networks versus Markets in International Trade'. Journal of International Economics, 48(1): 7-35.

Razzolini, T., and D. Vannoni (2011). 'Export Premia and Subcontracting Discount: Passive Strategies and Performance in Domestic and Foreign Markets'. The World Economy, 34(6): 9841013.

Schank, T., C. Schnabel, and J. Wagner (2010). 'Higher Wages in Exporting Firms: Self-Selection, Export Effect, or both? First Evidence from Linked Employer-Employee Data'. Review of World Economics, 146(2): 303-22.

Sharpston, M. (1975). 'International Sub-Contracting'. Oxford Economic Papers, 27(1): 94-135.

Su, J., and Y. Sun (2011). 'Informal Finance, Trade Credit, and Private Firm Performance'. Nankai Business Review International, 2(4): 383-401.

Sun, S.L., M.K. Peng, B. Ren, and D. Yan (2012). 'A Comparative Ownership Advantage Framework for Cross-Border M\&As: The Rise of Chinese and Indian MNEs'. Journal of World Business, 47(1): 4-16.

Tas, N.F., and L. van Oyen (2000). 'Assistance to Industrial SMEs in Vietnam: Moving Towards a Conducive Policy Framework and Improved Business Development Services'. UNIDO Private Sector Development Branch Technical Working Paper No. 5. Vienna: United Nations Industrial Development Organization.

UNU-WIDER, Central Institute for Economic Management (CIEM), and the Institute of Labour Science and Social Affairs (ILSSA) (various years). 'Survey of Small and Medium Scale Manufacturing Enterprises (SMEs) in Viet Nam, 2011, 2013, and 2015'. Helsinki: UNUWIDER.

Wagner, J. (2014). 'Credit Constraints and Exports: A Survey of Empirical Studies Using FirmLevel Data'. Industrial and Corporate Change, 23(6): 1477-92.

Waldron, D.G. (1995). 'Informal Finance and the East Asian Economic "Miracle". Multinational Business Review, 3(2): 46-55.

Wattanapruttipaisan, T. (2002). 'SME Subcontracting as a Bridgehead to Competitiveness: An Assessment of Supply-Side Capabilities and Demand-side Requirements'. Asia-Pacific Development Journal, 9(1): 65-87.

Wolf, H.C. (2000). 'Intranational Home Bias in Trade'. The Review of Economics and Statistics, 82(4): 555-63.

World Bank (2013). Skilling up Vietnam: Preparing the Workforce for a Modern Market Economy. Washington, DC: The World Bank.

World Bank (2015). World Development Indicators Databank. Available at: http://data.worldbank.org/data-catalog/world-development-indicators (accessed 29 December 2015).

World Bank (2016a). Doing Business 2016: Measuring Regulatory Quality and Efficiency. Economy Profile 2016: Vietnam. Washington, DC: The World Bank.

World Bank (2016b). World Development Indicators Databank. Available at: http://data.worldbank.org/data-catalog/world-development-indicators (accessed 28 September 2016).

WTO (World Trade Organization) (2013). 'Trade Policy Review: Vietnam'. Secretariat Report WT/TPR/S/287. Available at: https://www.wto.org/english/tratop_e/tpr_e/tp387_e.htm (accessed 29 December 2015). 
WTO (World Trade Organization) (2015). 'Trade Profile for Vietnam'. Available at: http://stat.wto.org/CountryProfiles/VN_e.htm (accessed 24 September 2016).

WTO (World Trade Organization) (2017). 'WTO Members Welcome Entry into Force of the Trade Facilitation Agreement'. Available at: https://www.wto.org/english/news_e/news17_e/fac_27feb17_e.htm (accessed 23 March 2017). 